Miriam Marcén ～ORCID iD: 0000-0002-1944-4790

\title{
The effect of culture on home-ownership
}

\author{
Miriam Marcén $^{1}$ and Marina Morales ${ }^{1}$ \\ ${ }^{1}$ Universidad de Zaragoza, Zaragoza, Spain
}

Corresponding Author: Miriam Marcén

Universidad de Zaragoza

Gran Vía 2

50005 Zaragoza (Spain)

mmarcen@unizar.es

Telephone: +34876554684

Marina Morales

Universidad de Zaragoza

Gran Vía 2

50005 Zaragoza (Spain)

mcmorales@unizar.es

Telephone: +34876554620

\begin{abstract}
In this paper, we analyze the role of culture in determining whether, or not, an individual is a homeowner. We use data on first-generation immigrants who arrived in the United States under six years old. Following the epidemiological approach, any dissimilarity in the proportion of homeowners by country of origin may be interpreted as a consequence of cultural differences. Our estimates indicate that there is a positive and statistically significant relationship between the cultural proxy and the immigrants' choice of home-ownership. Additionally, we present evidence of different mechanisms of transmission of culture, which reinforces our results on the cultural effect.
\end{abstract}

Keywords: Culture, Immigrants, Home-ownership

This article has been accepted for publication and undergone full peer review but has not been through the copyediting, typesetting, pagination and proofreading process, which may lead to differences between this version and the Version of Record. Please cite this article as doi: 10.1111/jors.12433.

This article is protected by copyright. All rights reserved. 
JEL Codes: J15, R20, Z13

This research has been funded by the Regional Government of Aragon and the European Fund of Regional Development (Grant S32_17R).

\section{INTRODUCTION}

Home-ownership has been found to have considerable socio-economic and demographic consequences, including impacts on household behavior, wealth, wages, mobility, labor-force participation, life satisfaction, physical and psychological health, and children's outcomes, as well as on urban structure and segregation (Aaronson, 2000; Coulson \& Fisher, 2009; Dietz \& Haurin, 2003; Green \& White, 1997; Goodman \& Mayer 2018; Haurin, Parcel, \& Haurin, 2002; Munch, Rosholm, \& Svarer, 2008). Policy-makers have also traditionally considered home-ownership as an important public policy (Goodman \& Mayer, 2018). Nonetheless, at the country level, there is no clear pattern of convergence of home-ownership behavior (Fisher \& Jaffee, 2003; Goodman \& Mayer, 2018). Researchers have explored the possible determinants affecting the home-ownership decision, focusing on housing market conditions (Chiuri \& Jappelli, 2003), mortgage markets (Badarinza, Campbell, \& Ramadorai, 2016), tax regulations (Bourassa \& Hoesli, 2010), employment and marital status (Feijten, 2005), political instability (Mudrazija \& Butrica, 2017), income (Fisher \& Jaffee, 2003), and demographic variables (Fisher \& Jaffee, 2003; Goodman \& Mayer, 2018), among others. Although all the factors mentioned here can influence home-ownership patterns, there can be other possible cross-country dissimilarities that may matter, as Goodman and Mayer (2018) indicate. In this paper, we consider the role of cultural differences in the home-ownership decision.

This article is protected by copyright. All rights reserved. 
Culture is defined by the United Nations Educational, Scientific and Cultural Organization (UNESCO, 2001) as "the set of distinctive spiritual, material, intellectual, and emotional features of society or a social group. Not only does this encompass art and literature, but it also includes lifestyles, ways of living together, value systems, traditions, and beliefs”. These beliefs and values cannot easily be measured and compared across countries, due to the interrelationships among institutions (such as capital and mortgage markets), economic conditions, and social norms/culture in each country (Fernández, 2007). For this reason, Fernández (2007) proposes an epidemiological approach to isolate the cultural effect from the institutional and economic conditions. Thus, the cultural effect is not used to describe differences in capital and mortgage markets (institutional environment). We concentrate on individual preferences and beliefs, broadly defined, as culture. In this setting, we examine the behavior of immigrants who arrived in the US at, or younger than, age five. Those immigrants have grown up under US markets, laws, institutions, and economic conditions, but their attitudes are probably similar to the preferences of their parents, forebears, and ethnic communities. Then, following the epidemiological approach, if the proportion of homeowners in the country of origin can explain the variations in home-ownership outcomes of first-generation immigrants, even after controlling for their individual characteristics, only the cultural component of this variable can be the determinant of this correlation (Fernández, 2007).

Our work contributes to the growing research on the effect of culture on socio-economic and demographic outcomes (Fernández, 2011; Giuliano, 2016). Using methodologies analogous to ours, there is empirical evidence of the effect of culture on living arrangements (Giuliano, 2007), women’s labor-force participation 
and fertility (Bellido, Marcén, \& Molina, 2016; Contreras \& Plaza, 2010; Fernández, 2007; Fernández and Fogli, 2006, 2009; Marcén, Molina, \& Morales, 2018), self-employment (Marcén, 2014), the search for a job (Eugster, Lalive, Steinhauer, \& Zweimüller, 2016), the living-together decision (Marcén \& Morales, 2018), divorce (Furtado, Marcén, \& Sevilla, 2013), and even on the math gender gap (Nollenberger, Rodríguez, \& Sevilla, 2016). Related to our paper is the work of Rodríguez-Planas (2018), who finds a cultural impact on the probability of having a mortgage, using data on immigrants living in Spain in 2007, a boom year for immigration and access to buying a house. Her conclusions are only applicable to individuals who decide to get a mortgage and, as she indicates, she focuses on the existence of a cultural financial liability. In our case, we focus on the homeownership culture, although we also consider the possible cultural effect on both home-ownership and having a mortgage.

In the literature, a few studies suggest the possible existence of a relationship between ethnicity and home-ownership, but they primarily compare immigrant and native behavior (Krivo, 1995). In general, studies show that immigrants are much less likely to own their own homes than are natives (Cahill \& Franklin, 2013), pointing to the assimilation process in the host country as the main determinant of the home-ownership gap. For example, Constant, Roberts, and Zimmermann (2009) show that immigrants in Germany, classified in six different ethnicities, with a strong commitment to the host country, are more likely to achieve home-ownership. In the United States, Chinese immigrants are less likely to own their own homes than are the native population of Los Angeles, with Chinese ethnicity being an important factor in determining housing outcomes (Painter, Yang, \& Yu, 2004). As Borjas (2002) explain, they also suggest that 
ethnic enclaves increase the probability of immigrants owning their own home. We add to this body of research by using home-ownership data as evidence that immigrants maintain similar home-ownership behavior to that of their counterparts in their respective countries of origin, suggesting that culture is important in the home-ownership decision.

To run our main analysis, we use data from the 2016 American Community Survey (ACS) of the Integrated Public Use Microdata Series (IPUMS) (Ruggles, Genadek, Goeken, Grover, \& Sobek, 2017). The cultural proxy is measured by utilizing data from the Integrated Public Use Microdata Series International (IPUMS International), Minnesota Population Center (2017), which allows us to calculate the variable of interest more precisely, as in Marcén et al. (2018) and Marcén and Morales (2018). Results point to culture being an important factor in home-ownership. We find a positive and statistically significant relationship between the probability of immigrants in the US reporting being a homeowner, and the proportion of their counterparts who are homeowners in their respective countries of origin or ancestry. This is maintained after adding controls for observable and unobservable characteristics (including country of origin fixed effects), regardless of the definition of the cultural proxy, using different subsamples, and carrying out several robustness checks considering same- and different-origin couples. Note that the inclusion of the country of origin fixed effects is important in order to show additional evidence that our cultural proxy is not capturing other characteristics that could vary at the country of origin level.

The last section presents evidence of the possible mechanisms of cultural transmission. Following Fernández and Fogli (2009) and Borjas (2002), we study whether culture is transmitted within communities. The possibility of vertical or This article is protected by copyright. All rights reserved. 
inter-generational transmission cannot be directly explored, since there is no available data on parents' characteristics. However, we can study whether immigrants are sensitive to the concentration of elderly individuals of the same ethnicity, which can be considered as a channel for the intergenerational transmission of culture (Marcén \& Morales, 2018). Similarly, we are able to study how culture operates horizontally by examining whether an increase in the concentration of old individuals of the same country of origin has an impact on the number of individuals who report being homeowners. Gender roles are also taken into account as potential determinants of how culture operates. All our findings reinforce the idea that culture is a significant factor in the home-ownership decision.

The remainder of the paper is organized as follows. Section 2 describes the data. Section 3 presents the empirical strategy. Our results are discussed in Section 4, and Section 5 concludes.

\section{DATA}

We utilize data from the 2016 American Community Survey (ACS) of Integrated Public Use Microdata Series (IPUMS) (Ruggles et al. 2017) in our main analysis. Our sample consists of first-generation immigrants, aged 18 to 69 years old, who arrived in the United States when they were aged five or younger. ${ }^{1}$ We select those immigrants who are heads of household or householders, in order to include one observation per household. ${ }^{2}$ The sample is restricted to those individuals who live in identifiable metropolitan areas in the ACS data. In addition, we restrict our sample to those individuals reporting information about their country of origin and their home-ownership status. The main sample consists of 8,313 observations of 
heads of household who are early-arrival immigrants living in MSAs and coming from 48 countries of origin. ${ }^{3}$

Several studies using the epidemiological approach to identify the importance of culture on socio-economic and demographic variables concern second-generation immigrants, selected because they have been exposed to US markets and institutions their entire lives. In this setting, they are unlikely to suffer from language barriers and have not experienced the shock of immigration (Fernández, 2007; Fernández \& Fogli, 2006, 2009; Giuliano, 2007). To determine whether an individual can be classified as second-generation, information on the birth place of the parents is needed, which is not always available. The ACS, for example, does not provide that information. Alternatively, Furtado et al. (2013) and Marcén et al. (2018) propose the use of young-arrival, first-generation immigrants since they can be considered quite similar to a sample of second-generation immigrants. Early-arrival immigrants, like second-generation immigrants, have been exposed to US conditions almost their entire lives and are not likely to have language barriers (Furtado et al., 2013). As Myers, Gao, and Emeka, (2009) explain, the impact of early arrival is important for English proficiency.

With respect to the cultural proxy, we consider the home-country proportion of homeowners. Prior literature measuring home-ownership rates for a large sample of countries, such as Fisher and Jaffe (2003), usually consider data provided by international organizations or government websites. In our case, we calculate our cultural proxy using data from the Integrated Public Use Microdata Series International (IPUMS International). This dataset provides harmonized data obtained from 365 censuses in 94 countries (Minnesota Population Center, 2017). Because we are interested in home-ownership, we have also chosen those countries 
with available information on whether a member of the household owns the housing unit. Unfortunately, we do not have information about home-ownership for all countries. ${ }^{4}$ To calculate our cultural proxy, we select country-of-origin Censuses as close as possible to the year 2016 (see Table A2 in the Appendix), since our empirical strategy relies on the fact that the behavior of early-arrival, first-generation immigrants who respond to the 2016 ACS is similar to the behavior of their counterparts in their country of origin, in the same period of time. ${ }^{5}$ We have also maintained the same sample selection as that used for the early-arrival first generation immigrants; that is, a sample of heads of household aged 18 to $69 .{ }^{6}$ Then, the home country home-ownership rate is the proportion of heads of household who own their residence (total number of heads of household aged 18 to 69 who are home-owners, in country of origin $j$, over the total number of heads of household aged 18 to 69 in country of origin $j$ ).

That way of calculating the cultural proxy provides one measure of culture for each country. However, we have also extended this by utilizing several measures of culture for each country of origin, as in Marcén et al. (2018) and Marcén and Morales (2018). This is necessary, because the use of one measure of culture is based on the assumption that culture does not differ within each country, which may generate concerns about the validity of the results. It should be noted that the sample of first-generation immigrants may not exhibit a similar composition to that of the population in the country of origin. For example, immigrants can be younger, or more likely to be unmarried, than their counterparts living in the home country. To address this issue, we measure the cultural proxy more precisely to capture the preferences and beliefs of different groups of individuals with similar characteristics in each country of origin. Following the 
proposal of Marcén et al. (2018), the cultural proxy is defined by country of origin, marital status, age, and employment status. This is defined in detail in the Results Section.

Summary statistics are displayed in Table 1 for the main variables, classified from the lowest to the highest home-country proportion of homeowners. As can be seen, there are considerable differences in the number of individuals who are homeowners among countries of origin, from 33 percent in Switzerland to 96 percent in Hungary. This is calculated using the IPUMS International. The average of homeowners is 70 percent, which is quite similar to that presented in Goodman and Mayer (2018) for the year 2015 (at 69.6 percent). As mentioned above, although many factors can determine those home-ownership dissimilarities, it is possible to argue that housing tenure outcomes cannot only be explained within a standard framework that accounts only for socio-economic, demographic, and housing market characteristics. For example, countries like Austria and Switzerland have sophisticated financial architectures, which can guarantee easy access to mortgages but they have low rates of home-ownership; in contrast, Vietnam, with high ownership rates has less well-developed credit markets. Thus, the existence of a home-ownership culture may also matter. We examine this with a sample of firstgeneration immigrants. The rest of the columns in Table 1 describe our main sample of first-generation immigrants living in the US. Overall, 61 percent of the immigrants are homeowners, with those originating from Bolivia having the highest percentages (see column 2). By simply comparing the information obtained from the IPUMS International and that of the immigrants living in the US, in columns 1 and 2, a relationship between the behavior of the immigrants and that of their counterparts is not clearly observed.

This article is protected by copyright. All rights reserved. 
It is also observed dissimilarities across immigrants in terms of gender composition, age, level of education, household composition, and marital status, by country of origin. Around 50 percent of immigrants are men, with this varying from just 32 percent in the case of immigrants from Iraq, to 67 percent in the case of those from Ethiopia. These first-generation immigrants are around 43 years old, on average, with the youngest being from Armenia, at 32 years old, and the oldest from Austria, at 61 years old. Regarding education, 27 percent of the immigrants have completed high school, with the lowest percentage being from Bangladesh and Malaysia, with no individual at this educational level, and the highest from Mexico (41 percent). With respect to those who have completed at least a college degree, the lowest percentages are observed among those originating from Mexico (45 percent), and the highest among those from Bangladesh and Malaysia (100 percent). For household composition, 40 percent of immigrants have a child under the age of sixteen living in the household, with this ranging from a low of 8 percent for Austria and Hungary to a high of 56 percent for Malaysia. Our sample also presents dissimilarities in marital status: 27 percent of immigrants are singles or never married, with the lowest percentages for those from Jordan (5 percent), and the highest from Trinidad and Tobago (46 percent). All these differences in the composition of immigrants by country of origin are taken into account in our analysis by incorporating several variables to avoid the possibility that our results could be driven by these individual characteristics.

The use of the 2016 American Community Survey (ACS) can generate concerns because of the proximity of the economic crisis, which may affect the home-ownership decisions of immigrants living in the US. To mitigate this concern, we show data on the proportion of homeowners, calculated for all 
immigrants with information, from 2007 to 2016, and the same proportion for native US population (see Figure 1). Similar to what we find in the literature (Borjas, 2002; Coulson, 1999), home-ownership is, on average, lower for immigrants than for the native US population. That home-ownership gap is maintained during the economic crisis. Moreover, Figure 2 shows that the relationship between the proportion of immigrant homeowners in 2007 and the proportion of immigrant homeowners in 2016 in the U.S, by country of origin, is quite similar. Those who tend to choose to own a home in a low (high) proportion in 2007 also maintain a low (high) proportion in 2016. Thus, the behavior of immigrants by country of origin does not appear to change in the period under consideration.

\section{EMPIRICAL STRATEGY}

To determine the impact of culture on the home-ownership decision, we follow an epidemiological approach using data on early-arrival first-generation immigrants living in the US. Since these individuals grew up under the same US markets, laws, and institutions, if only the environmental factors are important in the homeownership decision, the home-country proportion of their counterparts owning a home, which is the proxy of the culture or social norms, should have no effect on the home-ownership decision of those immigrants. If culture does play a role, we would expect to find a relationship between the behavior of the immigrants living in the US and that of their counterparts in their countries of origin. We examine this issue by estimating the following equation: ${ }^{7}$

$$
Y_{i j k}=\beta_{0}+\beta_{1} H C P H_{j}+\boldsymbol{X}_{i j k} \boldsymbol{\beta}_{2}+\boldsymbol{\delta}_{\boldsymbol{k}}+\boldsymbol{\eta}_{\boldsymbol{j}}+\varepsilon_{i j k}(1)
$$

This article is protected by copyright. All rights reserved. 
with $Y_{i j k}$ being a dummy variable that takes value one when immigrant $i$ of cultural origin $j$ living in Metropolitan Statistical Area (MSA) $k$ reports owning a home, and zero otherwise. The cultural proxy, $\mathrm{HCPH}_{j}$, is the proportion of homeowners in the country of origin $j$. We revisit that measure of the cultural proxy below. In any case, if culture plays a role here, immigrants originating from countries whose counterparts tend to choose to own a home in a high proportion, should have a higher likelihood of being homeowners. In this setting, we would expect $\beta_{1}$ to be positive. The vector $\boldsymbol{X}_{i j k}$ includes individual characteristics, such as gender (being a man, or not), age and its square, education level (no high school graduate (omitted), high school graduate, some college, more college (more than four years of college), marital status (being single or never married, or not) and household composition (having children under sixteen living at home, or not). ${ }^{8}$ The inclusion of gender is necessary because we choose those first-generation immigrants who are heads of household and, as we have described above, there are variations in the proportion of men by country of origin. Since men have traditionally been the breadwinners, and thus have the economic capacity to buy a home, cross-country-of-origin differences in the proportion of homeowners could be simply explained by differences in the proportion of men in each immigrant group. Other researchers also indicate that the variations in the home-ownership decisions may be the result of dissimilarities in the age of the individuals and their level of education, for reasons independent of culture (Chiuri \& Jappelli, 2003; Coulson, 1999). Thus, this should be taken into consideration in our regressions by controlling for those individual characteristics. With respect to the household composition, the literature documents that household composition is an important determinant in homeownership rates. As Constant et al. (2009) show, being married and having children 
under the age of sixteen increases the probability of home-ownership. As before, the variations across countries of origin of these characteristics could be explaining the cross-country variations in the proportion of homeowners. To address this issue, we have incorporated dummies to control for whether the head of household is single or never married, and whether there is any child below the age of sixteen in the household. In addition, we control for unobservable variables across the US by introducing MSA fixed effects, denoted by $\delta_{k}$ and for the country of origin unobserved characteristics, by introducing country of origin fixed effects, $\boldsymbol{\eta}_{\boldsymbol{j}}{ }^{9}$

The empirical strategy described above allows us only to analyze the impact of culture on the home-ownership decision. We have also extended our work using alternative methodologies to explore the choice of owning a home living with a partner of the same ethnicity, or not, and to the analysis of home-ownership and taking on a mortgage. This is explained in detail in Section 4.

An alternative strategy to study the cultural effect would be the inclusion of dummy variables for the various countries of origin, rather than controlling directly for the home-ownership rate in these countries, as in Giuliano (2007). The benefit of this approach is that it does not require a linear relationship as our model establishes between the cultural proxy and the dependent variable. However, this technique does not allow for a clear specification of how culture matters (Furtado et al., 2013). First, because of the large number of countries of origin (48), which makes it difficult to interpret the coefficients in terms of culture. Second, country of origin dummies not only capture the differences in the home-ownership across countries, but also other unobservable characteristics that vary at the country level. Then, the interpretation of those coefficients would be tricky, because it is not clear 
that we would be capturing the home-ownership culture by only using country of origin dummies.

\section{RESULTS}

\subsection{Baseline model}

Table 2 reports the estimates of Equation 1, with the cultural proxy defined as the home-country proportion of homeowners $(\mathrm{HCPH})$. Our results appear to be consistent with the prior literature. Being male and having children under the age of sixteen increases the probability of home-ownership (Constant et al., 2009). As Goodman and Mayer (2018) show, the older the individuals, the more likely they are to be homeowners. The impact of age has an inverted U-shape, achieving the maximum at 83 years old. Note that our immigrants are all below the age of 83 . The estimates for the education level controls are also consistent with the existing empirical results, since higher levels of education are related to greater probabilities of home-ownership (Coulson, 1999; Constant et al., 2009; Goodman and Mayer, 2018). Being single or never married decreases the probability of owning one's own dwelling. This result is also in line with the literature suggesting that married individuals are more likely to be homeowners (Feijten, 2005; Constant et al., 2009).

The estimated coefficient on the cultural proxy $(\mathrm{HCPH})$ indicates that a higher proportion of homeowners in an immigrant's country of origin is associated with an increase in the probability that that immigrant reports owning his/her home (see column 1). We observe that, when the cultural proxy (HCPH) increases by 1 percentage point, there is a rise of around 0.23 percentage points in the probability that an immigrant reports being a homeowner in the US. The cultural proxy in 
column 1 is measured as the home-country proportion of homeowners, by including only one measure of culture for each home country, which is the usual strategy in the research on the cultural effect. However, the use of just one cultural proxy by home country does not take into account the heterogeneity within countries of origin, which is a common problem in much of the literature on the cultural effect. For example, the preferences and attitudes regarding homeownership can differ within each home country, depending on marital status. In some countries, individuals who decide to buy a home when they are singles can be stigmatized, whereas, in other countries, being a homeowner while single may be socially accepted. If this heterogeneity is transmitted to the preferences and beliefs of our sample of immigrants, the inclusion of additional controls does not take into consideration the cultural variations within each home country. As in Marcén et al. (2018), we can use alternative cultural proxies, measuring the culture more precisely by country of origin and marital status, with the marital status being classified as: married/unmarried couple, single or never married, separated or divorced, and widow. ${ }^{10}$ Thus, we are capable of incorporating four different measures of the home-ownership culture for each home country.

Social norms (or culture) can also vary across age groups within each country of origin. Owning a home may be more socially acceptable for older individuals than for young individuals. The possible cultural differences across marital status and age group can easily be observed by plotting the relationship between the proportion of homeowner immigrants in the US, and the proportion of their counterparts owning a home by country of origin, marital status, and age group, in Figures 3 and 4. We have included those individuals who are aged 31 to 56, and two marital-status groups (married/unmarried couples and singles or never 
married) as an example. In both cases, we observe the expected positive relationship between the two variables: the larger the home-country proportion of homeowners, the greater the proportion of immigrants who decide to own a home in the US. Nonetheless, while, for example, in Ireland and Pakistan, individuals tend to choose to buy a home in a similar proportion when they are married/unmarried couples, we observe considerable differences between those two countries for the category single or never married individuals: 43 percent of single individuals in Ireland choose to buy a home on average, while 74 percent of single individuals in Pakistan decide to be homeowners. As before, to tackle this issue, were define our cultural proxy as the proportion of homeowners by country of origin, marital status, and age group, considering four age intervals: 18 to 30, 31 to 43, 44 to 56, and 57 to 69 . In this case, we incorporate in our estimations 16 different measures of culture for each home country. The differences across age groups and employment status by home country may also generate concerns about how and for whom the home-ownership culture may play a role. Again, to address this issue, we repeat the same analysis with our cultural proxy calculated by country of origin, marital status, age group, and employment status (employed, unemployed, and not in the labor force). In this context, there are 48 different measures of culture for each home country.

Results are shown in Table 2, where the home-country cultural proxy is added by marital status in column 2, by marital status and age group in column 3 , and by marital status, age group, and employment status in column $4 .{ }^{11}$ The use of these definitions of the cultural proxy, with more than one measure of culture by country of origin, permits us to add country of origin fixed effects to capture the unobserved heterogeneity across countries. This is important because, without 
those fixed effects, the estimated coefficient of the cultural proxy could be picking up the effect of culture in addition to, or instead of, the impact of other unobservable characteristics that vary at the home country level, and that may also affect home-ownership decisions. In all cases (columns 2 to 4), we find a positive relationship between the home-country proportion of homeowners (regardless of the categories included in the cultural proxy) and the probability that an immigrant owns a home in the US. All these specifications include Metropolitan Statistical Areas (MSAs) fixed effects and country of origin fixed effects. ${ }^{12}$ These estimates provide empirical evidence pointing to the fact that we are capturing the impact of culture on the home-ownership decision. The magnitude of the effect is considerably larger in column 2 than in the rest of the columns. In that specification, our cultural proxy has been calculated by marital status and country of origin, and our results point to an increase of 0.55 percentage points in the probability of being a homeowner in the US, when the cultural proxy (HCPH) increases by 1 percentage point. Therefore, comparing countries of origin, immigrants from countries where their counterparts tend to choose to buy a home in a high proportion (for example, Hungary), are about 34.5 percentage points more likely to be homeowners in the US because of the impact of culture, than immigrants from countries with a low $\mathrm{HCPH}$ (for example, Switzerland). It is worth noting that after redefining our main explanatory variable by groups, it can be surmised that we are over-controlling for age and marital status. To mitigate this concern, we repeat the analysis by excluding controls for age and marital status in column 5 . Our findings do not change. ${ }^{13}$ For the rest of the analysis, we consider the home-country cultural proxy by marital status in most of the specifications. Results are unchanged when we use the other measures of culture. In any case, 
Goodman and Mayer (2018) explain that the age-pattern of home-ownership in the United States is similar to that of other countries: the older the individuals, the more likely they are to be homeowners. Thus, cultural differences could be more important by marital status across countries of origin. ${ }^{14}$

Since, in the literature, female heads of household have been found to be less likely to own a home than married non-head-of-household women (Haurin \& Kamara, 1992), our results may be driven by gender differences. This can be more problematic, since we only consider, at this point of the analysis, the information on head of household though, as we have described above, we use a genderbalanced sample, on average. We revisit this issue below. In any case, we separate the sample by gender to explore the existence of possible gender issues in our estimations. Results are displayed in columns 6 and 7 for men and women, respectively. In both cases, we find that the home-country proportion of homeowners is positively related to the probability of home-ownership for immigrants (men and women, separately). Thus, our results do not appear to depend on gender differences.

Although all our sample of US early-arrival immigrants have grown up in the same country, the US, it can be argued that US markets, laws, and institutions are not equal in all states. Then, since immigrant groups are likely to cluster within particular parts of the US, it is possible to surmise that we are capturing differences in US states, in addition to (or instead of) the cultural effect of the country of origin. As mentioned above, we have run our analysis adding MSA fixed effects, which should pick up those differences - in our case, at a lower level than the state level. To examine this further, we check the consistency of our results by adding the proportion of homeowners by US state, in column 8 of Table 2. This variable is 
supposed to capture differences in home-ownership behavior across the US. Our findings do not change: neither the sign nor the magnitude of the coefficient of the cultural proxy.

We also report simple robustness checks by repeating the analysis without the two countries with the highest and the lowest home-country proportion of homeowners (Hungary and Switzerland), to check whether this affects our estimates. Results are presented in columns 1 and 2 of Table 3. Our estimates do not change. We conclude the same in observing column 3, where we eliminate those immigrants from Mexico, which is the country with the largest number of observations. We also repeat the analysis utilizing a subsample of immigrants aged 30 to 50 years old, to reduce concerns about heterogeneity across age groups. ${ }^{15}$ Estimated coefficients are shown in column 4 of Table 3. We find that the impact of our cultural proxy remains statistically significant and the magnitude of the effect is slightly greater than that previously obtained.

Until now, we have obtained the cultural proxy using information on the country of origin for the year 2016, or the closest available. This relies on the notion that the behavior of immigrants living in the US in 2016 is similar to their counterparts living in their home country in that year. Nevertheless, since culture is transmitted from parents to their children when they are young (Furtado et al., 2013), it can be argued that the preferences and beliefs of immigrants are quite similar to those of their parents when they arrived in the US, so to calculate the cultural proxy we should consider information on home-ownership in the countries of origin some decades earlier. Our immigrants are 43 years old on average in 2016, so information on home-ownership in the 1970s can represent the culture that their parents transmitted. ${ }^{16}$ Results do not change, (see column 5 of Table 3), which 
is not surprising since culture changes slowly, as Fernández (2007) asserts. ${ }^{17}$ It is also possible to argue that our results depend on the ACS data used in our analysis. We only consider the 2016 ACS in the main analysis. Although the behavior of the immigrants does not appear to change substantially over time, as observed in Figures 1 and 2, this is not conclusive. To provide further empirical evidence in favor of our findings, we extend our sample to include information from the 2014, 2015, and 2016 ACS. This gives us a larger sample of immigrants. Results are unchanged (see column 6 of Table 3). Then, the possible changes on the composition of the immigrant sample do not appear to lead to different findings.

The choice of heads of household characteristics in the main analysis is also a possible problem for the validity of our estimations, as mentioned above. We can easily check whether our conclusions vary after the incorporation of heads of household and their immigrant partners, if any, in our sample. Estimated points are reported in column 7 for the entire sample, in column 8 for men, and in column 9 for women. The positive relationship between the cultural proxy and the probability of being a homeowner is observed. It is reassuring that, regardless of the measure of the cultural proxy, and even after dividing the sample by gender, the effect of culture is still present.

As prior research suggests, economic or political changes that occurred in some countries are responsible for different waves of migration to the US (Villarreal, 2014), which can affect our estimates. To address this issue, we control for the timing of migration by adding dummies for the year of migration, in column 1 of Table 4. Our results remain similar to those previously described, suggesting that the differences in the year of migration do not have an impact on our regressions. Moreover, we analyze whether immigrants' sensitivities to their home- 
country culture differ, depending on their time of migration, by including interaction terms between our cultural proxy and the period of migration fixed effects. Because of the large number of interactions that this generates, we had to redefine the time of migration fixed effects using dummies for the decade in which the immigrants arrived in the US. ${ }^{18}$ Results are shown in columns 2 and 3 (with a sample of individuals older than 30). Regardless of the decade of migration, the estimated cultural effect is always positive, although for the case of those arriving in the 1990s and 2000s, it is not statistically significant (and the magnitude of the coefficient is lower). This may be due to the fact that younger cohorts were more affected by the crisis than older ones. As Myers, Lee, and Simmons, (2019) explain, younger individuals have delayed home buying because of the Great Recession. We choose a sample of early-arrival first-generation immigrants who arrived in the US at or below the age of five, so that all those arriving in the 1990s and 2000s are the youngest individuals in our sample. We have repeated the analysis with a sample of individuals older than 30, who are supposed to be less affected in their home-ownership decision by the last recession, and our findings clearly point to the cultural effect (see column 3). Similarly, we can also examine this issue by including interaction terms between our cultural proxy and the age of individuals in our sample. As before, we redefine the age of individual fixed effects using dummies by age interval (18-29 (omitted), 30-39, 40-49, 50-59 and 60-69 years old). Results show that, for the youngest individuals (18-29), the cultural effect is the lowest and it is only statistically significant at the 10 percent level. Again, a possible explanation is that the ownership decision of young individuals could be more affected by the recent Great Recession by, for instance, the postponement of buying a home (Myers et al. 2019), than by the cultural effect. It 
can also be surmised that, since the negative impact that immigrant status has on the probability of home-ownership decreases over time (Coulson, 1999), those young immigrants needs more time to behave as their counterparts in their country of origin. ${ }^{19}$

For additional empirical evidence that our results are not affected by heterogeneity across countries, the analysis has been repeated incorporating controls for observable characteristics of the countries of origin, in Table 5. We include the unemployment rate, GDP per capita (in constant 2010 \$US), the female labor-force participation rate, a property prices index, and a property rights index. ${ }^{20}$ As prior research suggests, the probability of owning a home can be influenced by those factors that impact housing availability and affordability (Clark, Deurloo, \& Dieleman, 1997; Rodríguez-Planas, 2018). The exclusion of those variables can be problematic if those observable characteristics vary at the country level, and are correlated with our variable of interest, the cultural proxy. In this setting, it could be that our cultural proxy is picking up the effect of those determinants on the home-ownership decision. Table 5 presents the estimations incorporating all the measures of the cultural proxy considered in Table 2 (columns 1 to 4), as well as separating the sample by gender (columns 5 and 6 ). ${ }^{21}$ We find, again, a positive association between the cultural proxy and the probability of being a homeowner. In short, all the estimations described in this section indicate that culture can affect the home-ownership decision.

This article is protected by copyright. All rights reserved. 


\subsection{First mortgage, second mortgage, and the home-ownership decision: The cultural effect}

Recently, Rodríguez-Planas (2018) has suggested that there is a financial culture on the decision to have mortgage financing. She follows the epidemiological approach and finds that mortgage financing in the home country is a factor in the immigrants' mortgage decision in the host country. This can be related to our framework, since to be able to buy a house, in most cases, people need mortgage financing. In her paper, the possible existence of social norms regarding homeownership is not considered. With respect to home-ownership issues, she only adds the property rights index at the country of ancestry level. Although we do not focus on the possible impact of culture on mortgage financing, it could be that we are capturing the social norms affecting mortgage financing, in addition to, or instead of, those regarding home-ownership. This is also a possible problem in the work of Rodríguez-Planas (2018), since she could be confounding both culture regarding home-ownership and social norms regarding mortgage financing in her estimates. It can be argued that home-ownership is only attractive for those with positive attitudes regarding mortgage financing and so they are the only ones who can afford the payment for their own home. The opposite can also be surmised, that is, it is possible that only those immigrants originating from countries of origin where home-ownership is socially acceptable are the immigrants who consider mortgage financing more acceptable. The separation of both social norms is tricky. Unfortunately, we only have information on whether our sample of heads of household own their own dwelling but are encumbered by a mortgage, in the 2016 ACS. There is no information about the immigrants who have paid off their mortgages in 2016 or some years before.

This article is protected by copyright. All rights reserved. 
In this setting, we can only check whether our conclusions vary when we separate the sample between those reporting owning a house with a mortgage and those that do not report having that debt. Results are shown in column 1 (excluding those individuals without a mortgage and with the dependent variable taking the value of one when an immigrant reports being a homeowner with a mortgage and zero otherwise), and column 2 (excluding those individuals with a mortgage and with the dependent variable taking the value of one when an immigrant reports being a homeowner and zero otherwise) of Table 6 . In both cases, regardless of the definition of the dependent variable and the subsample considered, we observe a positive relationship between the cultural proxy and the probability of being a homeowner in the US, pointing to the importance of culture as a factor in determining home-ownership.

The ACS also provides information on whether owner-occupied housing units with a first mortgage were encumbered by a second mortgage or home equity loan. To provide additional estimates in favor of the cultural effect, we have extended the analysis, including first and second mortgages. We propose the use of a model for nominal outcomes, specifically a Multinominal Logit Model (MNL) in which we calculate a separate binary logit for each pair of outcome categories (Nervole and Press, 1973). Formally, we estimate the following equation:

$$
\ln \varphi_{m \mid b}=\ln \frac{\operatorname{Pr}(y=m \mid \mathbf{x})}{\operatorname{Pr}(y=b \mid \mathbf{x})}=\mathbf{x}^{\prime} \boldsymbol{\beta}_{\boldsymbol{m} \mid \boldsymbol{b}} \text { for } m=1 \text { to } J(2)
$$

with $b$ being the base category and $m$ varying from one to $J$. $J$ is the total number of outcome categories, in our case, four (not being a homeowner, being a homeowner without mortgage, owning a house encumbered by only a first mortgage, owning a house encumbered by a second mortgage). The vector $\mathbf{x}$ also includes the controls 
that we have defined above. Results are presented in columns 3 to 5 of Table $6 .^{22}$ In order to study the dynamics among the outcome categories, we use odds ratios, (Greene, 2008; Long and Freese, 2014). Holding other variables constant, the changed factor in the odds of outcome category $m$ versus outcome category $n$, when $x_{i}$ increased by $\delta$, equals:

$$
\frac{\varphi_{m \mid n}\left(\boldsymbol{x}, x_{i}+\delta\right)}{\varphi_{m \mid n}\left(\boldsymbol{x}, x_{i}\right)}=e^{\boldsymbol{\beta}_{\mathbf{i}, \mathbf{m} \mid \mathbf{n}} \delta}
$$

For a unit change in $x_{i}, \delta=1$, the odds of $m$ versus $n$ are expected to change by a factor of $\exp \left(\beta_{i, m \mid n}\right)$, holding all other variables constant. For a standard deviation change in $x_{i}, \delta=s_{x_{i}}$, the odds of $m$ versus $n$ are expected to change by a factor of $\exp \left(\beta_{i, m \mid n} \times s_{x_{i}}\right)$. The odds ratios have been plotted in an odds-ratio plot in Figure 5 to be easily interpreted (Long \& Freese, 2014). Our variable of interest, the cultural proxy, and the rest of the controls are represented in separate rows. The horizontal axis measures the relative magnitude of the coefficients associated with each outcome category. The numbers correspond to the outcome categories: "one" denotes not being a homeowner, which is the base category in that figure, "two" is a homeowner without a mortgage, "three" owning a house encumbered by only a first mortgage, and "four" being a homeowner with a first mortgage, but also encumbered by a second mortgage. The distance between a given pair of outcome categories indicates the magnitude of the effect, and the statistical significance is shown by drawing a line between categories for which there is no statistically significant coefficient at the 10 percent level of significance. Results suggest that the greater the proportion of homeowners in the country of ancestry of our sample of immigrants, the less likely is the category one (not being a homeowner). Then, the choice would be the categories two or three, but between 
them there are no statistically significant differences. This is not surprising, since we do not know whether those homeowners without mortgage (category two) afforded a house with a mortgage but they have already paid off that mortgage in 2016, when the information for this survey was collected. In any case, both categories are to the right of the category not being a homeowner, suggesting that the cultural proxy matters in the home-ownership decision. What is not so predictable is that the higher the cultural proxy, the more willing are immigrants to take on debt - not only by way of a first mortgage, but also with a second mortgage. Thus, the more acceptable is home-ownership in an immigrant's home country, the more likely is that the immigrant takes on debt in order to buy a house in the host country. Being aware of the weaknesses of the information on mortgage finance, it is comforting that all these estimates suggest that culture is a factor in the homeownership decision.

\subsection{The effect of culture on home-ownership: Same origin partner or not}

Previously, we have performed the analysis using the characteristics of the country of ancestry of our householder first-generation immigrants, where the decision to own a house is attributed to the characteristics, preferences, and beliefs of only one of the members of the household (the householder). Nevertheless, in those cases in which the householder has a married or unmarried partner, the characteristics of the other member of the couple may also be a factor in the home-ownership decision of the couple. There are two alternatives, having a partner of the same ethnicity, or having a partner of a different ethnicity. ${ }^{23}$ We first explore whether the cultural effect is detected in the case of married or unmarried couples having a partner of the same ethnicity. Table 7 includes the estimated points. Column 1, which 
includes only a sample of couples with a partner of the same ethnicity, reveals similar results to those described above. The greater the proportion of married and unmarried couples who report being homeowners in the country of ancestry, the greater the probability of being homeowners in the US for a couple from that country of ancestry.

In the case of couples of different origin or ethnicity, it can be supposed that the preferences of the heads of household's partners are driving our findings. ${ }^{24}$ In column 2 of Table 7, we incorporate as a measure of culture the HCPH of the head of household's partner (HH's partner). Although there is a positive relationship, which is not surprising since both the HCPH of the heads of household and that of their partners is positively related, the coefficient capturing this new measure of the cultural proxy is only significant at the 10 percent level. An explanation for this finding could be that we are adding to that regression the country of origin of the heads of household fixed effects, and this can be highly correlated with the home country cultural proxy of the heads of household's partner. The same is observed in column 3, where we have dropped the country of origin fixed effects because they cannot be used in this specification (since we have included the cultural proxy of the head of household defined with only one measure of culture for each home country). ${ }^{25}$ In column 3, only the cultural proxy of the head of household's partner is statistically significant, but not that of the head of household. As mentioned above, this could be due to the fact that both are highly correlated. Alternatively, we include the mean between both cultural proxies of the head of household and his/her partner as a proxy of the home-ownership culture in that house. This measure of culture is included in column 4. As can be seen, there is a positive effect of the variable of interest on the probability of owning a home in the US, but 
again only at the 10 percent significance level. In columns 2 to 4 , the sample used only includes couples with different ethnicities. We also check whether the redefinition of the cultural proxy as the mean $\mathrm{HCPH}$ of both members of the couple affects our initial sample. First, we consider the entire sample but excluding those immigrants with a partner for whom the Census provided by the IPUMS International has no information (see column 5). Then, with the sample of column 5, we maintain the same cultural proxy with the exception of that of differentorigin couples, in which the mean $\mathrm{HCPH}$ of both members of the couple is utilized in column 6. The magnitude of the effect does not vary so much. The main sample is incorporated in the last column, column 7 , where the redefinition of the cultural proxy for those couples of different origin, having information on the cultural proxy for both members of the couple, does not alter our findings.

\subsection{The mechanisms through which culture operates}

From the previous analysis, it is possible to infer that culture affects the homeownership decision. This subsection explores the possible channels of transmission of culture. Furtado et al. (2013), Marcén et al. (2018), and Marcén and Morales (2018) explain that the vertical transmission of culture cannot be examined because we do not have information on parents' characteristics in some of the US Census and ACS data. However, home-ownership culture can also be transmitted horizontally, through neighbors, friends, or the ethnic communities in which immigrants live. Following the existing literature, we study the horizontal transmission of culture, analyzing whether immigrants' sensitivities to the homecountry proportion of homeowners vary depending on whether they live in predominantly same-ethnicity communities. Fernández and Fogli (2009) also point to this mechanism of cultural transmission since local/ethnic communities maintain

This article is protected by copyright. All rights reserved. 
culture either by providing role models for acceptable behavior, or by punishing deviance from the social norm/culture. In this setting, we consider the possible existence of network effects in order to identify that horizontal transmission of culture, as Bertrand, Luttmer, and Mullainathan (2000) do, with the following model:

$$
Y_{i j k}=\beta_{0}+\beta_{1} P_{j k}+\beta_{2} P_{j k} * H C P H_{j}+\boldsymbol{X}_{i j k} \boldsymbol{\beta}_{3}+\boldsymbol{\delta}_{\boldsymbol{k}}+\boldsymbol{\eta}_{\boldsymbol{j}}+\varepsilon_{i j k}(4)
$$

where $P_{j k}$ is the proportion of immigrants from the same country of origin $j$ in each metropolitan area $k$. The remaining variables have been defined above. Our variable of interest is the interaction between ethnic concentration and the homecountry proportion of homeowners. If there is a horizontal transmission of culture, we would expect that an increase in the concentration of same-ethnicity immigrants will increase the probability of home-ownership, more for immigrants originating from countries with a high proportion of homeowners than for those from countries with a low proportion of homeowners. Then, $\beta_{2}$ should be positive.

Table 8 shows the estimations of Equation 4. In the first column, ethnic concentration appears to have no effect on the probability of being a homeowner. The same occurs after adding the cultural proxy in column 2. The concentration coefficient is not statistically significant, but the home-country cultural proxy has the expected positive sign and the magnitude is the same value as in our baseline specification, in column 2 of Table 2. The interaction between the ethnic concentration and the HCPH is added in column 3, as in Furtado et al. (2013). In that case, the coefficient capturing the effect of the ethnic concentration is negative and statistically significant, and the interaction term is positive and statistically significant, indicating that, depending on the HCPH level, the effect of the ethnic 
concentration varies from positive to negative. This result may be interpreted as follows: an increase of 10 percentage points in the concentration of immigrants from Switzerland leads to a decrease of 0.11 in the probability of home-ownership for those immigrants in the US (the proportion of homeowners in Switzerland is 0.33). The same increase in the concentration of immigrants from Hungary results in an increase of 0.08 in the probability of home-ownership for Hungarians (the proportion of homeowners in Hungary is 0.96 ). An increase in the concentration of individuals of the same ethnic community appears to lead to a decrease in the probability of owning a home for individuals originating from countries where their counterparts tend to be homeowners in a low proportion, while an increase in the probability of owning a home is observed for those originating from countries with a high proportion of homeowners.

Prior studies point to the growth of ethnic enclaves in major American cities as an important factor in increasing immigrant demand for owner-occupied housing in many metropolitan areas. However, as before, such studies do not examine the different patterns by establishing a relationship between homeownership behavior and those in the country of origin. Borjas (2002) suggests that ethnic enclaves increase the probability that immigrant households own their homes, although our results reveal that this is only true at certain levels of $\mathrm{HCPH}$. Of course, we recognize that this is not a full-proof method of identifying the horizontal transmission of culture but, it is reassuring that our estimations suggest that immigrants are sensitive to their ethnic communities, providing additional empirical evidence that social norms/culture may play a role.

Another channel through which culture may operate is the respect for elders, as Marcén and Morales (2018) suggest. Since many societies are This article is protected by copyright. All rights reserved. 
distinguished by the importance of respect for the elderly and the maintenance of family bonds (Jambunathan, Burts, \& Pierce, 2000; Wakil, Siddique, \& Wakil, 1981), it is possible that an individual decides to be a homeowner in obedience to, or respect for, the traditions of the elderly members of their communities. Being conscious of the scarcity of data on this issue, we can only follow the same strategy as before, examining whether immigrants' sensitivities to the cultural proxy change depending on whether they live in predominantly older same-ethnicity communities. As can be seen in column 4, the coefficient picking up the effect of the proportion of the elderly of the same origin is negative and statistically significant, whereas that of the interaction term is positive and statistically significant. This indicates that the impact of the concentration of same-ethnicity elders varies from negative to positive, depending on the level of the cultural proxy, which may in turn suggest that culture is operating through respect for the older members of the community.

The gender roles may lead to different levels of home-ownership culture assimilation. To tackle this issue, we follow the proposal of Gay, Hicks, SantacreuVasut, and Shoham (2017) and Marcén and Morales (2018), by controlling whether a language employs a grammatical gender system, based on biology, or not; individuals speaking a language with a gender-based system are more likely to follow traditional norms. Information is compiled by linguists in the World Atlas of Language Structures Online (Dryer \& Haspelmath, 2013). ${ }^{26}$ Assuming that more traditional norms imply a higher proportion of individuals owning their own homes by those individuals originating from more traditional cultures (considering the gender-based language systems), we see a greater impact of the home country cultural proxy. When the cultural proxy $(\mathrm{HCPH})$ increases by 1 percentage point in 
countries of origin with gender-based language systems (countries not using gender-based language systems), there is a rise of around $0.555(0.420)$ percentage points in the probability that an immigrant reports owning a house in the US (see column 5 of Table 8). The results described in this section provide evidence of some of the channels (ethnic enclaves, respect for the elderly, and gender roles) through which culture may be transmitted and may operate, providing supplementary empirical evidence in favor of the existence of a cultural effect in the home-ownership decision.

\section{CONCLUSIONS}

Cross-country differences in the proportions of home-ownership have not varied considerably in recent decades (Goodman \& Mayer, 2018). The literature points to several factors as possible determinants of those dissimilarities, such as housing market conditions, mortgage markets, tax regulations, and demographic conditions, among others. However, even these institutional and economic factors cannot fully explain cross-country variation. For example, the access to sophisticated financial architectures, such as that of Austria or Switzerland, does not assure high homeownership rates. In contrast, there can be observed quite high home-ownership rates in less well-developed credit markets, such as that of Vietnam. Thus, following Goodman and Mayer (2018), who suggest that culture may also play a role here, we examine the possible cultural effect on home-ownership. To pick up the effects of culture apart from those of markets, laws, and institutions (such as capital and mortgage markets) in determining the home-ownership decision, we follow an epidemiological approach (Fernández, 2007), using data on immigrants arriving in the US when very young, from the 2016 ACS. Since all of these individuals grew up under the same US laws, markets, and institutions, we can 
interpret any positive relationship between the home-country proportion of homeowners and the decision to own a home in the US, as evidence that culture matters in the decision.

To the best of our knowledge, there is no prior research on this issue. In the literature, researchers point to ethnicity as an important factor in explaining the home-ownership gap between natives and immigrants, showing that more integrated immigrants in the host country are more likely to achieve homeownership (Constant et al., 2009). Then, they focus on the comparison between natives and immigrants. Our paper builds on prior work, analyzing the homeownership differences within immigrant populations. We study the relationship between immigrants' home-ownership behavior and that of their counterparts in their respective countries of origin, in order to explore the cultural effect.

We find evidence of a positive and statistically significant effect of the cultural proxy on the likelihood that an immigrant owns a home. The impact of culture is greater when the cultural proxy is measured more precisely within each country of origin, calculating the cultural proxy by marital status, age, and employment status, in order to take into account the heterogeneity within countries of ancestry as in Marcén et al. (2018) and Marcén and Morales (2018). Results are robust to controls for observable and unobservable characteristics by country of ancestry, and to the use of different subsamples. It is worth noting that we have detected a low impact of culture on the youngest individuals. A possible explanation of this result is that their ownership decision could be driven by recent Great Recession (Myers et al. 2019), diminishing the cultural effect.

This article is protected by copyright. All rights reserved. 
The possible existence of a mortgage-finance culture has also been considered in our analysis. Using the epidemiological approach, Rodríguez-Planas (2018) has explored mortgage-finance culture using Spanish data. This is related to our work, although it is not clear whether it is the home-ownership culture or the mortgage culture that matters, or whether both are important in the homeownership decision. We present several scenarios of owning a home: without a mortgage, with only a first mortgage, and with a second mortgage. The cultural proxy is always positively related to those three possibilities, which again points to the possible existence of a cultural effect. Recognizing the scarcity of mortgagefinance data, what is remarkable from our analysis is that the more acceptable is home-ownership in an immigrant country of origin, the greater the probability that the immigrant will take on debt in order to afford a house in the host country.

The exploration of alternative kinds of household, such as same- or different-origins, provides additional empirical evidence of the cultural effect. With a sample of same-origin couples, our conclusions do not vary, and the cultural proxy is positively related to the probability of owning a home. For different-origin couples, we have checked several samples and definitions of the cultural proxy in order to include the culture of the head of household's partner. Again, all our results point to the possibility that culture can be a determinant in the homeownership decision.

Finally, the transmission of culture has also been explored in this work. With the available data, we can only study the horizontal transmission (ethnic communities) of culture but not the vertical transmission (from parents to their offspring). Other researchers have also analyzed the possible effect of ethnic enclaves on home-ownership, without considering the cultural issue as we do here 
(following Furtado et al., 2013). Our analysis is interesting since we observe that the effect of ethnic concentration varies from positive to negative depending on the $\mathrm{HCPH}$ level. Specifically, we find that, for high levels of HCPH, immigrants are sensitive to the behavior of their ethnic communities, increasing the probability of being homeowners. However, for low levels of HCPH, the concentration of sameethnicity individuals discourages immigrants from choosing to own a home. Additionally, we examine other possible ways through which culture may operate, such as respect for the elders and gender roles. In both cases, we find evidence that there can be transmission of culture through those channels.

\section{Acknowledgments}

We thank the editor and the anonymous reviewer for their careful reading and their insightful comments and suggestions.

\section{Appendix}

\section{Table A1: The effect of culture on the home-ownership decision using Probit Models}

Notes: The home-country proportion of homeowners is calculated using information from the IPUMS International. The sample, obtained from the 2016 ACS, consists of immigrants aged 18 to 69 who arrived in the US at or before the age of 5 and who report a country of origin. In the first column, the home-country cultural proxy has been calculated by country of origin. In columns 2 to 4, that variable has been measured by marital status, marital status and age group, and marital status, age group and employment status, respectively. Estimates are weighted. Robust standard errors, clustered by country of origin, are in parentheses. *** Significant at the 1 percent level, ** Significant at the 5 percent level, * Significant at the 10 percent level

Dependent variable: Homeowner

$\mathrm{HCPH}$

$0.652 *$

HCPH by marital status
(2)

(3)

(4)
(0.374)

$1.277^{* * *}$

This article is protected by copyright. All rights reserved. 
HCPH by marital status and age

Man

$$
0.137^{* * *} \quad 0.122^{* * *} \quad 0.120^{* * *}
$$

$\operatorname{Age}^{2} / 100$

$\begin{array}{llll}(0.010) \quad(0.011) & (0.010) \quad(0.008)\end{array}$

High school graduate

$\begin{array}{cccc}-0.036 * * * & -0.037 * * * & -0.010 & -0.010 \\ (0.011) & (0.012) & (0.010) & (0.009)\end{array}$

Some college

$\begin{array}{cccc}0.089 & 0.080 & 0.094 * & 0.099 * \\ (0.055) & (0.051) & (0.054) & (0.055)\end{array}$

Some college

$0.269 * * * \quad 0.258 * * * \quad 0.261 * * * \quad 0.284 * * *$

$\begin{array}{llll}(0.062) & (0.071) & (0.071)\end{array}$

More college

$0.536^{* * *} \quad 0.507^{* * *} \quad 0.509^{* * *} \quad 0.514^{* * *}$

$(0.044) \quad(0.046) \quad(0.045) \quad(0.042)$

Children under sixteen

$0.240 * * *$

$0.202 * * *$

$0.221 * * *$

$0.216^{* * *}$

$(0.054)$

$(0.057)$

(0.055)

(0.058)

Single or never married

$-0.513^{* * *}$

$-0.320 * * *$

$-0.412 * * *$

$-0.437 * * *$

Observations

$(0.038) \quad(0.060) \quad(0.047) \quad(0.041)$

8,313

8,313

8,313

8,104

\section{Table A2: Home-Country Censuses from IPUMS} International

Notes: This table shows the Censuses of the countries of origin utilized to calculate the cultural proxies.

$\begin{array}{lcc}\text { Country } & \begin{array}{c}\text { 2016 Census Year } \\ \text { (IPUMS International) }\end{array} & \begin{array}{c}\text { 1970 Census Year } \\ \text { (IPUMS International) }\end{array} \\ \text { Argentina } & 2001 & 1970 \\ \text { Armenia } & 2011 & 2001\end{array}$

This article is protected by copyright. All rights reserved. 


\begin{tabular}{|c|c|c|}
\hline Austria & 2001 & 1981 \\
\hline Bangladesh & 2011 & 1991 \\
\hline Bolivia & 2001 & 1976 \\
\hline Brazil & 2010 & 1970 \\
\hline Canada & 2011 & 1981 \\
\hline Chile & 2002 & 1970 \\
\hline Colombia & 2005 & 1973 \\
\hline Costa Rica & 2011 & 1973 \\
\hline Dominican Republic & 2010 & 198 \\
\hline Ecuador & 2010 & 197 \\
\hline El Salvador & 2007 & 1992 \\
\hline Ethiopia & 2007 & 198 \\
\hline Fiji & 2007 & 1986 \\
\hline France & 2011 & 1968 \\
\hline Greece & 2011 & 1971 \\
\hline Haiti & 2003 & 1971 \\
\hline Hungary & 2011 & 1970 \\
\hline India & 1987 & 1987 \\
\hline Indonesia & 2010 & 1971 \\
\hline Iran & 2006 & $200 €$ \\
\hline Iraq & 1997 & 1997 \\
\hline Ireland & 2011 & 1981 \\
\hline Italy & 2001 & 200 \\
\hline Jamaica & 2001 & 200 \\
\hline Jordan & 2004 & 200 \\
\hline Kenya & 2009 & 198 \\
\hline Malaysia & 2000 & 197 \\
\hline Mexico & 2015 & 197 \\
\hline Morocco & 2004 & 198 \\
\hline
\end{tabular}

This article is protected by copyright. All rights reserved. 


\begin{tabular}{ccc} 
Nicaragua & 2005 & 1971 \\
Nigeria & 2010 & 2006 \\
Pakistan & 1998 & 1998 \\
Panama & 2010 & 1980 \\
Peru & 2007 & 1993 \\
Philippines & 1990 & 1990 \\
Poland & 2002 & 1978 \\
Portugal & 2011 & 1981 \\
Romania & 2011 & 1977 \\
Spain & 2001 & 1991 \\
Switzerland & 2000 & 1970 \\
Thailand & 2000 & 1970 \\
Trinidad and Tobago & 2011 & 1970 \\
Turkey & 2000 & 1985 \\
United Kingdom & 2001 & 1991 \\
Venezuela & 2001 & 1971 \\
Vietnam & 2009 & 1999 \\
\hline
\end{tabular}

\section{REFERENCES}

Aaronson, D. (2000). A note on the benefits of homeownership. Journal of Urban Economics, 47(3), 356-369.

Badarinza, C., Campbell, J. Y., \& Ramadorai, T. (2016). International comparative household finance. Annual Review of Economics, 8(1), 111-144.

Bellido, H., Marcén, M., \& Molina, J.A. (2016). The effect of culture on fertility behavior of US teen mothers. Feminist Economics, 22(3), 101-126.

Bertrand, M., Luttmer, E. F. P., \& Mullainathan, S. (2000). Network effects and welfare cultures. Quarterly Journal of Economics, 115(3), 1019-1055.

This article is protected by copyright. All rights reserved. 
Borjas, G. J. (2002). Homeownership in the immigrant population. Journal of Urban Economics, 52(3), 448-476.

Bourassa, S. C., \& Hoesli, M. (2010). Why do the Swiss rent?. The Journal of Real Estate Finance and Economics, 40(3), 286-309.

Cahill, M. E., \& Franklin, R. S. (2013). The minority homeownership gap, home foreclosure, and nativity: Evidence from Miami-Dade County. Journal of Regional Science, 53(1), 91-117.

Chiuri, M. C., \& Jappelli, T. (2003). Financial market imperfections and home ownership: a comparative study. European Economic Review, 47(5), 857-875.

Clark, W.A., Deurloo, M.C., \& Dieleman, F.M., (1997). Entry to home-ownership in Germany: Some comparisons with the United States. Urban Studies, 34(1), 719.

Constant, A. F., Roberts, R., \& Zimmermann, K. F. (2009). Ethnic identity and immigrant homeownership. Urban Studies, 46(9), 1879-1898.

Contreras, D., \& Plaza, G. (2010). Cultural factors in women's labor force participation in Chile. Feminist Economics, 16(2), 27-46.

Coulson, N. E. (1999). Why are Hispanic-and Asian-American homeownership rates so low?: Immigration and other factors. Journal of Urban Economics, 45(2), 209-227.

Coulson, N. E., \& Fisher, L. M. (2009). Housing tenure and labor market impacts: The search goes on. Journal of Urban Economics, 65(3), 252-264. 
Dietz, R. D., \& Haurin, D. R. (2003). The social and private micro-level consequences of homeownership. Journal of Urban Economics, 54(3), 401-450.

Dryer, M. S., \& Haspelmath, M. (Eds.) (2013). The World Atlas of Language Structures Online. Leipzig: Max Planck Institute for Evolutionary Anthropology. (Available online at http://wals.info, Accessed on 2018-08-09.)

Eugster, B., Lalive, R., Steinhauer, A., \& Zweimüller, J. (2016). Culture, work attitudes and job search: Evidence from the Swiss language border. Journal of the European Economic Association, 5(5), 1056-1100.

Feijten, P. (2005). Union dissolution, unemployment and moving out of homeownership. European Sociological Review, 21(1), 59-71.

Fernández, R. (2007). Women, work, and culture. Journal of the European Economic Association, 5(2-3), 305-332.

Fernández, R. (2011). Does culture matter. In Jess, Benhabib, Bisin, and Jackson (Eds.), Handbook of Social Economics, 1, 481-510. North-Holland.

Fernández, R., \& Fogli, A. (2006). Fertility: the role of culture and family experience. Journal of the European Economic Association, 4(2-3), 552-561.

Fernández, R., \& Fogli, A. (2009). Culture: an empirical investigation of beliefs, work, and fertility. American Economic Journal: Macroeconomics, 1(1), 146-177.

Fisher, L. M., \& Jaffe, A. J. (2003). Determinants of international home ownership rates. Housing finance international, 18(1), 34-37.

This article is protected by copyright. All rights reserved. 
Furtado, D., Marcén, M., \& Sevilla, A. (2013). Does culture affect divorce? Evidence from European immigrants in the United States. Demography, 50(3), 1013-1038.

Gay, V., Hicks, D. L., Santacreu-Vasut, E., \& Shoham, A. (2017). Decomposing culture: An analysis of gender, language, and labor supply in the household. Review of Economics of the Household, 1-29, doi.org/10.1007/s11150-017-9369-x.

Giuliano, P. (2007). Living arrangements in western Europe: Does cultural origin matter?. Journal of the European Economic Association, 5(5), 927-952.

Giuliano, P. (2016). Review of cultural evolution: society, technology, language, and religion. In J. Richerson J. \& H. Christiansen (Eds.), Journal of Economic Literature, 54(2), 522-533.

Goodman, L. S., \& Mayer, C. (2018). Homeownership and the American Dream. Journal of Economic Perspectives, 32(1), 31-58.

Green, R.K., \& White, M.J., (1997). Measuring the benefits of homeownership: Effects on children. Journal of Urban Economics, 41(3), 441-461.

Greene, W.H. (2008). Econometric analysis. New Jersey: Prentice Hall.

Haurin, D. R., Parcel, T. L., \& Haurin, R. J. (2002). Does homeownership affect child outcomes?. Real Estate Economics, 30(4), 635-666.

Haurin, D. R., \& Kamara, D. A. (1992). The homeownership decision of femaleheaded households. Journal of Housing Economics, 2(4), 293-309.

This article is protected by copyright. All rights reserved. 
Jambunathan, S., Burts, D. C., \& Pierce, S. (2000). Comparisons of parenting attitudes among five ethnic groups in the United States. Journal of Comparative Family Studies, 31(4), 395-406.

Krivo, L. J. (1995). Immigrant characteristics and Hispanic-Anglo housing inequality. Demography, 32(4), 599-615.

Long, J., \& Freese, J. (2014). Regression models for categorical dependent variables using Stata. 3rd ed. College Station, TX: US: Stata Press.

Marcén, M. (2014). The role of culture on self-employment. Economic Modelling, 44(1), s20-s32.

Marcén, M., Molina, J. A., \& Morales, M. (2018). The effect of culture on the fertility decisions of immigrant women in the United States. Economic Modelling, 70, 15-28.

Marcén, M., \& Morales, M. (2018). Live together: Does culture matter?. Review of Economics of the Household, 1-43. DOI: 10.1007/s11150-018-9431-3.

Minnesota Population Center (2017). Integrated Public Use Microdata Series, International: Version 6.5 [dataset]. Minneapolis, MN: University of Minnesota. https://doi.org/10.18128/D020.V6.5

Mudrazija, S., \& Butrica, B. A. (2017). Homeownership, Social Insurance, and Old-Age Security in the United States and Europe. Innovation in Aging, 1(1), 183184

Munch, J. R., Rosholm, M., \& Svarer, M. (2008). Home ownership, job duration, and wages. Journal of Urban Economics, 63(1), 130-145.

This article is protected by copyright. All rights reserved. 
Myers, D., Gao, X., \& Emeka, A. (2009). The Gradient of Immigrant Age-atArrival Effects on Socioeconomic Outcomes in the US. International Migration Review, 43(1), 205-229.

Myers, D., Lee, H., \& Simmons, P. A. (2019). Cohort Insights into Recovery of Millennial Homeownership after the Great Recession. Journal of Housing Economics, forthcoming.

Nervole, M., \& Press, S. (1973). Univariate and Multivariate Log-Linear and Logistic Models. Santa Monica, California: Rand Corporation.

Nollenberger, N., Rodríguez, N., \& Sevilla, A. (2016). The math gender gap: The role of culture. American Economic Review, 106(5), 257-261.

Painter, G., Yang, L., \& Yu, Z. (2004). Homeownership determinants for Chinese Americans: Assimilation, ethnic concentration and nativity. Real Estate Economics, 32(3), 509-539.

Rodríguez-Planas, N. (2018). Mortgage Finance and Culture. Journal of Regional Science, 58(4), 786-821.

Ruggles, S., Genadek, K., Goeken, R., Grover, J., \& Sobek, M. (2017). Integrated Public Use Microdata Series: Version 7.0 [dataset]. Minneapolis, MN: University of Minnesota. https://doi.org/10.18128/D010.V7.0.

United Nations Educational, Scientific \& Cultural Organization (UNESCO) (2001). Universal declaration on cultural diversity. In: 31st Session of the General Conference of Unesco.

This article is protected by copyright. All rights reserved. 
Villarreal, A. (2014). Explaining the decline in Mexico-US migration: The effect of the Great Recession. Demography, 51(6), 2203-2228.

Wakil, S. P., Siddique, C. M., \& Wakil, F. A. (1981). Between two cultures: A study of socialization of children of immigrants. Journal of Marriage and the Family, 43(4), 929-940.

This article is protected by copyright. All rights reserved. 
Figure 1: Evolution of the proportion of homeowner natives and the proportion of homeowner immigrants from 2007 to 2016.

Notes: Data come from the IPUMS USA

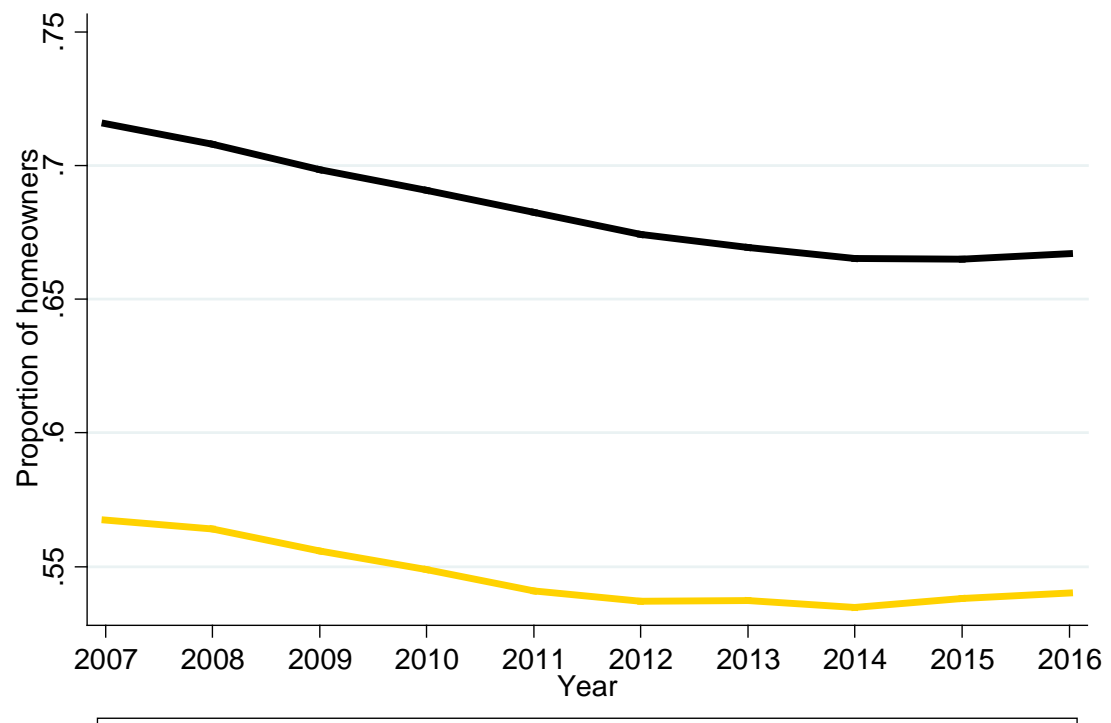

-Proportion of homeowner natives - Proportion of homeowner immigrants

Figure 2: Relationship between the proportion of homeowners in 2007 and the proportion of homeowners in 2016, by country of origin.

Notes: Data come from the IPUMS USA

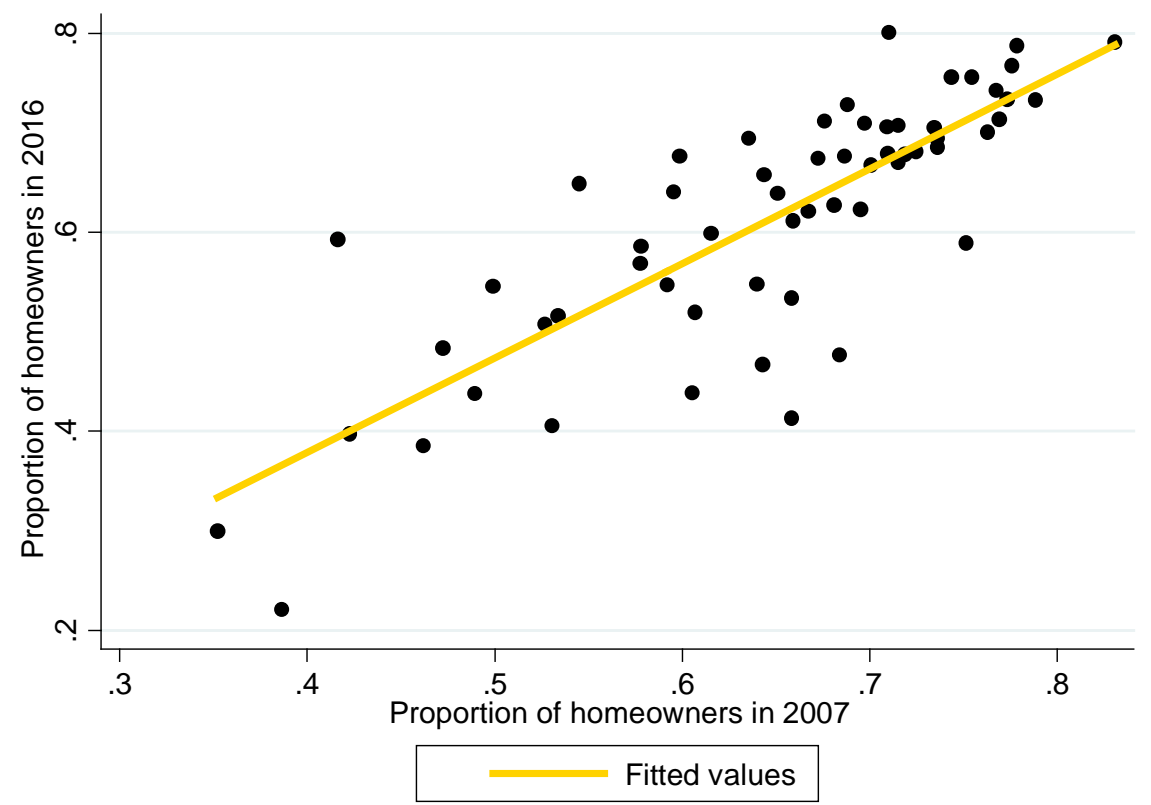

This article is protected by copyright. All rights reserved. 
Figure 3: The proportion of homeowner immigrants in the US, and the proportion of homeowners in their respective countries of origin. All married or unmarried and aged 31 to 56.

Notes: The home-country proportion of homeowners, calculated using data from the IPUMS International, is plotted on the $\mathrm{x}$-axis, while the proportion of homeowner immigrants of those countries of origin, calculated using data from the 2016 ACS, is plotted on the y-axis. In both cases, married individuals aged 31 to 56 are considered.

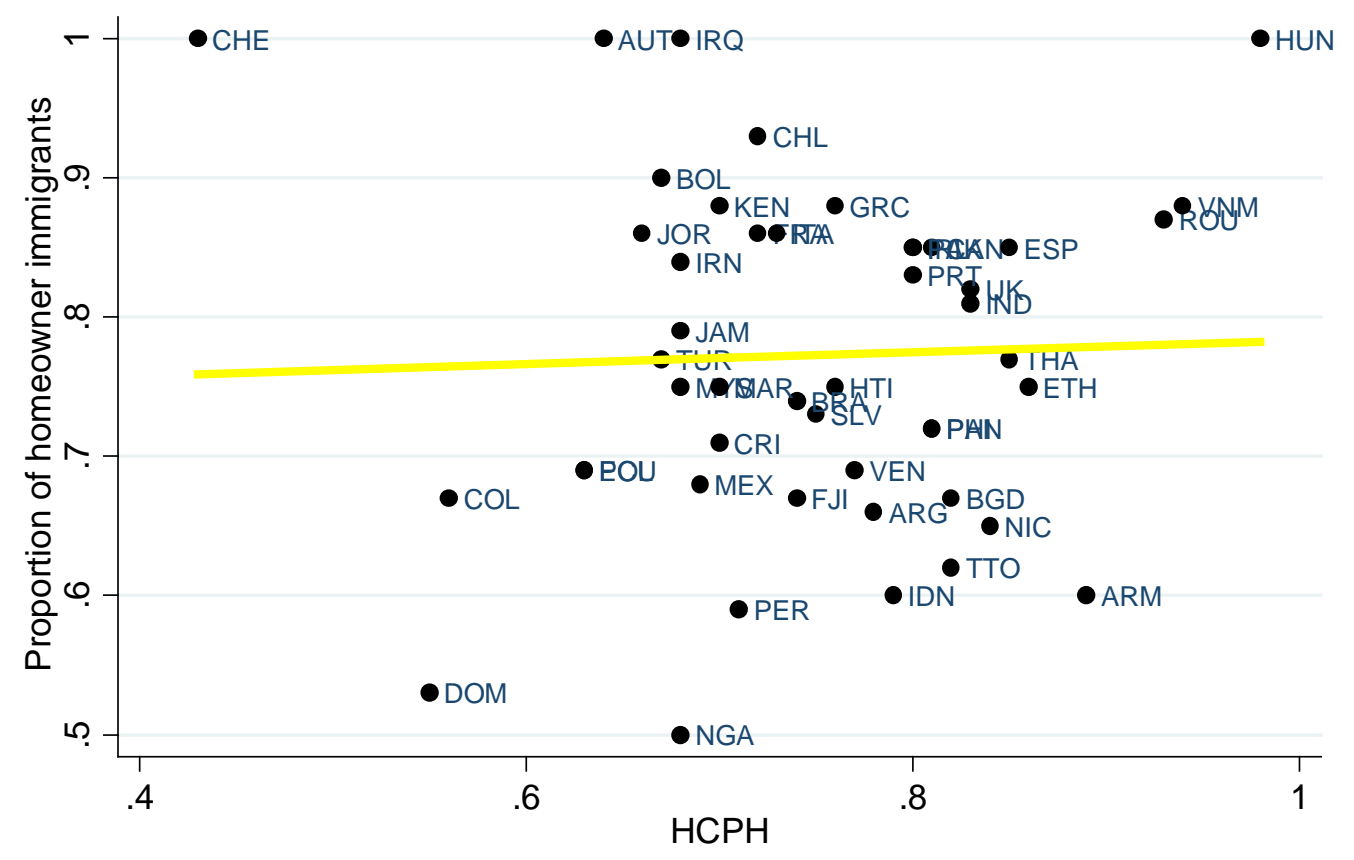

Fitted values

This article is protected by copyright. All rights reserved. 
Figure 4: The proportion of homeowner immigrants in the US, and the proportion of homeowners in their respective countries of origin. All single and aged 31 to 56.

Notes: The home-country proportion of homeowners, calculated using data from the IPUMS International, is plotted on the $\mathrm{x}$-axis, while the proportion of homeowner immigrants of those countries of origin, calculated using data from the 2016 ACS, is plotted on the y-axis. In both cases, single individuals aged 31 to 56 are considered.

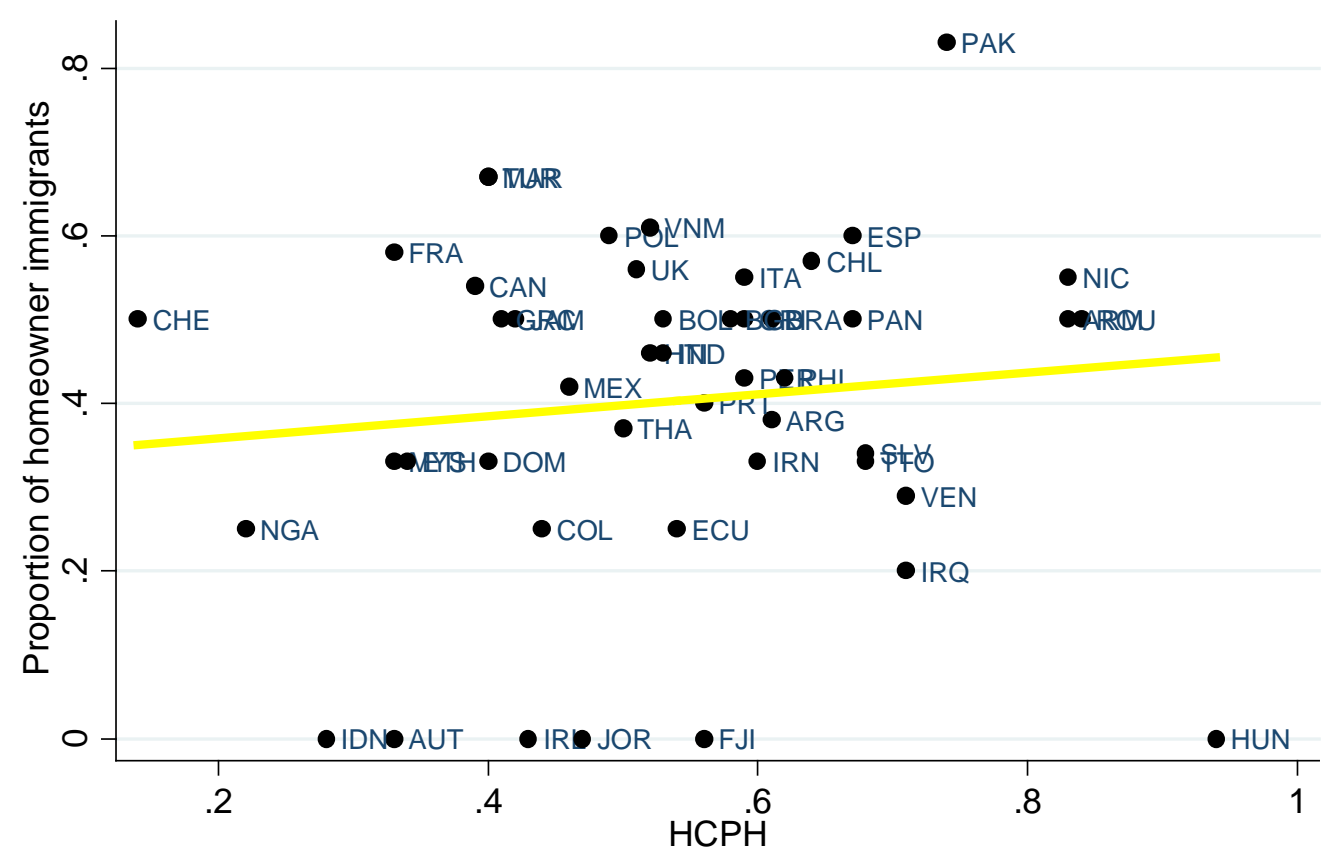

Fitted values

This article is protected by copyright. All rights reserved. 
Figure 5: No homeowner (outcome one), homeowner without mortgage (outcome two), owning a house encumbered by only a first mortgage (outcome three), being a homeowner with a first mortgage but also encumbered by a second mortgage (outcome four): using a Multinomial Logit.

Notes: Robust standard errors. The numbers correspond to the outcome categories: one indicates not being a homeowner, two indicates being a homeowner without mortgage, three indicates owning a house encumbered by only a first mortgage, and four being a homeowner with a first mortgage but also encumbered by a second mortgage. The statistical significance is shown by drawing a line between categories for which there is no significant coefficient at the 10 percent level.

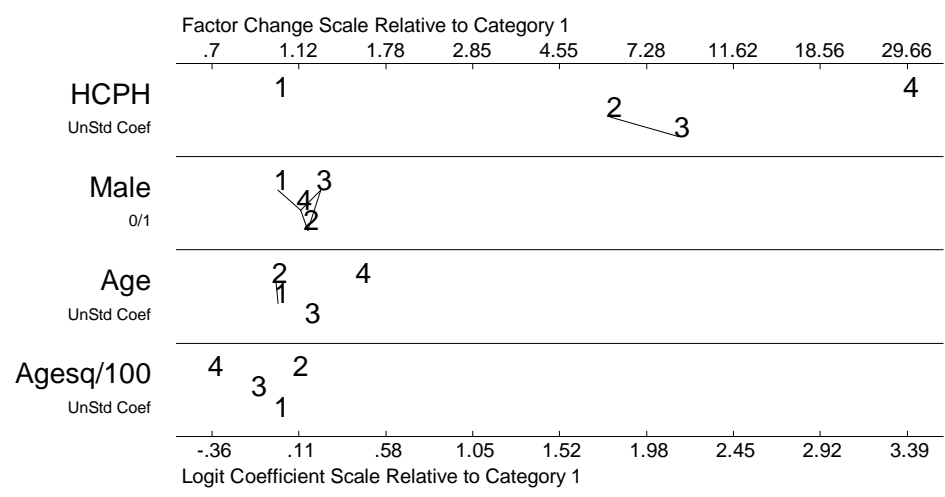

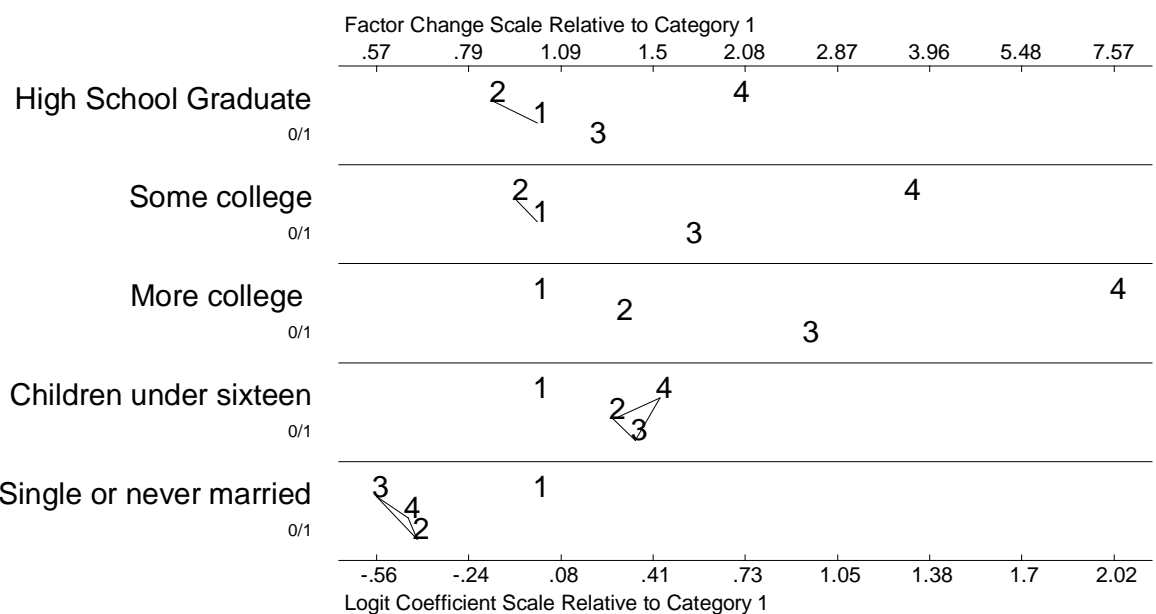

This article is protected by copyright. All rights reserved. 
Table 1: Summary statistics by country of origin

\begin{tabular}{|c|c|c|c|c|c|c|c|c|c|c|}
\hline Country & $\begin{array}{l}\text { Home } \\
- \\
\text { countr } \\
\text { y } \\
\text { cultur } \\
\text { al } \\
\text { proxy }\end{array}$ & $\begin{array}{l}\text { Proportio } \\
\text { n of } \\
\text { homeown } \\
\text { er } \\
\text { immigrant } \\
\text { s }\end{array}$ & $\begin{array}{c}\mathrm{Ma} \\
\mathrm{n}\end{array}$ & Age & $\begin{array}{c}\text { High } \\
\text { school } \\
\text { graduat } \\
\text { e }\end{array}$ & $\begin{array}{c}\text { Some } \\
\text { colleg } \\
\text { e }\end{array}$ & $\begin{array}{c}\text { More } \\
\text { colleg } \\
\text { e }\end{array}$ & $\begin{array}{l}\text { Childre } \\
\text { n under } \\
\text { sixteen }\end{array}$ & $\begin{array}{l}\text { Single } \\
\text { or } \\
\text { never } \\
\text { marrie } \\
\text { d }\end{array}$ & $\begin{array}{c}\text { Observatio } \\
\text { ns }\end{array}$ \\
\hline Switzerland & 0.33 & 0.68 & $\begin{array}{c}0.6 \\
1\end{array}$ & $\begin{array}{c}43.5 \\
2\end{array}$ & 0.06 & 0.06 & 0.87 & 0.32 & 0.23 & 31 \\
\hline Austria & 0.50 & 0.79 & $\begin{array}{c}0.4 \\
7\end{array}$ & $\begin{array}{c}61.1 \\
0\end{array}$ & 0.27 & 0.24 & 0.42 & 0.08 & 0.15 & 62 \\
\hline Jamaica & 0.53 & 0.56 & $\begin{array}{c}0.4 \\
3\end{array}$ & $\begin{array}{c}41.0 \\
4\end{array}$ & 0.21 & 0.21 & 0.57 & 0.37 & 0.41 & 104 \\
\hline $\begin{array}{l}\text { Dominican } \\
\text { Republic }\end{array}$ & 0.54 & 0.37 & $\begin{array}{c}0.4 \\
3\end{array}$ & $\begin{array}{c}38.6 \\
3\end{array}$ & 0.21 & 0.36 & 0.33 & 0.54 & 0.35 & 150 \\
\hline Colombia & 0.54 & 0.51 & $\begin{array}{c}0.4 \\
6\end{array}$ & $\begin{array}{c}41.6 \\
6\end{array}$ & 0.22 & 0.22 & 0.53 & 0.34 & 0.31 & 140 \\
\hline France & 0.54 & 0.77 & $\begin{array}{c}0.5 \\
5\end{array}$ & $\begin{array}{c}53.7 \\
7\end{array}$ & 0.27 & 0.21 & 0.51 & 0.14 & 0.16 & 238 \\
\hline Poland & 0.58 & 0.67 & $\begin{array}{c}0.5 \\
6\end{array}$ & $\begin{array}{c}44.3 \\
7\end{array}$ & 0.21 & 0.15 & 0.62 & 0.36 & 0.27 & 84 \\
\hline Ecuador & 0.62 & 0.49 & $\begin{array}{c}0.5 \\
3\end{array}$ & $\begin{array}{c}43.6 \\
1\end{array}$ & 0.19 & 0.34 & 0.45 & 0.30 & 0.27 & 74 \\
\hline Nigeria & 0.62 & 0.58 & $\begin{array}{c}0.5 \\
8\end{array}$ & $\begin{array}{c}37.3 \\
5\end{array}$ & 0.06 & 0.06 & 0.81 & 0.26 & 0.42 & 31 \\
\hline Ireland & 0.64 & 0.72 & $\begin{array}{c}0.4 \\
8\end{array}$ & $\begin{array}{c}51.6 \\
2\end{array}$ & 0.08 & 0.36 & 0.56 & 0.18 & 0.22 & 50 \\
\hline Bolivia & 0.65 & 0.81 & $\begin{array}{c}0.4 \\
4\end{array}$ & $\begin{array}{c}41.0 \\
0\end{array}$ & 0.13 & 0.31 & 0.56 & 0.50 & 0.25 & 16 \\
\hline Malaysia & 0.65 & 0.63 & $\begin{array}{c}0.6 \\
3\end{array}$ & 38.5 & 0.00 & 0.19 & 0.81 & 0.56 & 0.31 & 16 \\
\hline Mexico & 0.66 & 0.54 & $\begin{array}{c}0.4 \\
7\end{array}$ & $\begin{array}{c}39.5 \\
9\end{array}$ & 0.41 & 0.28 & 0.17 & 0.52 & 0.28 & 2,760 \\
\hline Jordan & 0.66 & 0.79 & $\begin{array}{c}0.6 \\
3\end{array}$ & $\begin{array}{c}48.0 \\
5\end{array}$ & 0.32 & 0.26 & 0.42 & 0.32 & 0.05 & 19 \\
\hline Kenya & 0.66 & 0.71 & $\begin{array}{c}0.5 \\
0\end{array}$ & $\begin{array}{c}44.2 \\
1\end{array}$ & 0.14 & 0.21 & 0.64 & 0.29 & 0.21 & 14 \\
\hline Turkey & 0.67 & 0.67 & $\begin{array}{c}0.4 \\
8\end{array}$ & $\begin{array}{c}47.1 \\
9\end{array}$ & 0.12 & 0.39 & 0.49 & 0.34 & 0.21 & 67 \\
\hline Canada & 0.68 & 0.73 & $\begin{array}{c}0.5 \\
5\end{array}$ & $\begin{array}{c}49.0 \\
4\end{array}$ & 0.20 & 0.22 & 0.57 & 0.24 & 0.23 & 725 \\
\hline
\end{tabular}

This article is protected by copyright. All rights reserved. 


\begin{tabular}{|c|c|c|c|c|c|c|c|c|c|c|}
\hline Iran & 0.68 & 0.71 & $\begin{array}{c}0.6 \\
2\end{array}$ & $\begin{array}{c}39.9 \\
5\end{array}$ & 0.11 & 0.21 & 0.68 & 0.51 & 0.24 & 76 \\
\hline Iraq & 0.68 & 0.59 & $\begin{array}{c}0.3 \\
2\end{array}$ & $\begin{array}{c}41.9 \\
1\end{array}$ & 0.32 & 0.18 & 0.50 & 0.36 & 0.36 & 22 \\
\hline Morocco & 0.68 & 0.62 & $\begin{array}{c}0.4 \\
1\end{array}$ & $\begin{array}{c}51.2 \\
2\end{array}$ & 0.27 & 0.24 & 0.41 & 0.16 & 0.32 & 37 \\
\hline Costa Rica & 0.69 & 0.48 & $\begin{array}{c}0.5 \\
6\end{array}$ & $\begin{array}{c}42.6 \\
0\end{array}$ & 0.12 & 0.36 & 0.52 & 0.36 & 0.28 & 25 \\
\hline United Kingdom & 0.69 & 0.70 & $\begin{array}{c}0.5 \\
3\end{array}$ & $\begin{array}{c}48.2 \\
5\end{array}$ & 0.22 & 0.24 & 0.52 & 0.25 & 0.24 & 721 \\
\hline Peru & 0.70 & 0.53 & $\begin{array}{c}0.5 \\
3\end{array}$ & $\begin{array}{c}42.4 \\
3\end{array}$ & 0.14 & 0.26 & 0.55 & 0.34 & 0.31 & 58 \\
\hline Greece & 0.70 & 0.68 & $\begin{array}{c}0.4 \\
7\end{array}$ & $\begin{array}{c}49.2 \\
5\end{array}$ & 0.27 & 0.21 & 0.52 & 0.31 & 0.22 & 77 \\
\hline Italy & 0.70 & 0.79 & $\begin{array}{c}0.5 \\
4\end{array}$ & $\begin{array}{c}51.9 \\
7\end{array}$ & 0.29 & 0.23 & 0.44 & 0.24 & 0.17 & 333 \\
\hline Chile & 0.71 & 0.77 & $\begin{array}{c}0.4 \\
9\end{array}$ & $\begin{array}{c}44.4 \\
1\end{array}$ & 0.15 & 0.13 & 0.69 & 0.33 & 0.28 & 39 \\
\hline Brazil & 0.72 & 0.62 & $\begin{array}{c}0.5 \\
3\end{array}$ & $\begin{array}{c}44.4 \\
6\end{array}$ & 0.24 & 0.21 & 0.51 & 0.38 & 0.29 & 76 \\
\hline Portugal & 0.72 & 0.75 & $\begin{array}{c}0.5 \\
3\end{array}$ & $\begin{array}{c}47.7 \\
8\end{array}$ & 0.32 & 0.25 & 0.29 & 0.34 & 0.18 & 96 \\
\hline Haiti & 0.73 & 0.52 & $\begin{array}{c}0.4 \\
0\end{array}$ & $\begin{array}{c}40.9 \\
8\end{array}$ & 0.14 & 0.26 & 0.59 & 0.36 & 0.40 & 58 \\
\hline Argentina & 0.73 & 0.66 & $\begin{array}{c}0.5 \\
2\end{array}$ & $\begin{array}{c}46.8 \\
4\end{array}$ & 0.15 & 0.26 & 0.56 & 0.34 & 0.25 & 61 \\
\hline Fiji & 0.73 & 0.45 & $\begin{array}{c}0.5 \\
5\end{array}$ & $\begin{array}{c}38.1 \\
8\end{array}$ & 0.36 & 0.36 & 0.27 & 0.55 & 0.18 & 11 \\
\hline El Salvador & 0.74 & 0.50 & $\begin{array}{c}0.5 \\
2\end{array}$ & $\begin{array}{c}37.9 \\
6\end{array}$ & 0.36 & 0.27 & 0.29 & 0.48 & 0.39 & 162 \\
\hline $\begin{array}{l}\text { Trinidad and } \\
\text { Tobago }\end{array}$ & 0.77 & 0.48 & $\begin{array}{c}0.4 \\
3\end{array}$ & $\begin{array}{c}41.3 \\
5\end{array}$ & 0.22 & 0.39 & 0.37 & 0.37 & 0.46 & 46 \\
\hline Venezuela & 0.77 & 0.57 & $\begin{array}{c}0.5 \\
6\end{array}$ & $\begin{array}{c}43.2 \\
2\end{array}$ & 0.13 & 0.19 & 0.65 & 0.22 & 0.28 & 54 \\
\hline Indonesia & 0.77 & 0.67 & $\begin{array}{c}0.5 \\
2\end{array}$ & $\begin{array}{c}41.7 \\
4\end{array}$ & 0.07 & 0.22 & 0.67 & 0.48 & 0.22 & 27 \\
\hline Panama & 0.79 & 0.69 & $\begin{array}{c}0.5 \\
5\end{array}$ & $\begin{array}{c}50.2 \\
7\end{array}$ & 0.25 & 0.22 & 0.51 & 0.25 & 0.16 & 134 \\
\hline Pakistan & 0.80 & 0.65 & $\begin{array}{c}0.5 \\
6\end{array}$ & $\begin{array}{c}35.6 \\
0\end{array}$ & 0.05 & 0.25 & 0.69 & 0.49 & 0.31 & 55 \\
\hline Spain & 0.81 & 0.76 & $\begin{array}{c}0.5 \\
3\end{array}$ & $\begin{array}{c}45.8 \\
8\end{array}$ & 0.23 & 0.21 & 0.56 & 0.32 & 0.19 & 04 \\
\hline
\end{tabular}




\begin{tabular}{|c|c|c|c|c|c|c|c|c|c|c|}
\hline Philippines & 0.81 & 0.55 & $\begin{array}{c}0.5 \\
2\end{array}$ & $\begin{array}{c}41.3 \\
8\end{array}$ & 0.14 & 0.32 & 0.53 & 0.43 & 0.29 & 498 \\
\hline Ethiopia & 0.81 & 0.57 & $\begin{array}{c}0.6 \\
7\end{array}$ & $\begin{array}{c}43.7 \\
1\end{array}$ & 0.10 & 0.19 & 0.67 & 0.29 & 0.29 & 21 \\
\hline Thailand & 0.82 & 0.59 & $\begin{array}{c}0.5 \\
0\end{array}$ & $\begin{array}{c}36.5 \\
1\end{array}$ & 0.22 & 0.30 & 0.45 & 0.55 & 0.40 & 152 \\
\hline India & 0.82 & 0.57 & $\begin{array}{c}0.5 \\
8\end{array}$ & $\begin{array}{c}36.9 \\
8\end{array}$ & 0.07 & 0.13 & 0.78 & 0.37 & 0.35 & 242 \\
\hline Bangladesh & 0.82 & 0.59 & $\begin{array}{c}0.4 \\
5\end{array}$ & $\begin{array}{c}32.7 \\
7\end{array}$ & 0.00 & 0.32 & 0.68 & 0.32 & 0.41 & 22 \\
\hline Nicaragua & 0.85 & 0.53 & $\begin{array}{c}0.4 \\
4\end{array}$ & $\begin{array}{c}36.9 \\
4\end{array}$ & 0.18 & 0.36 & 0.39 & 0.45 & 0.30 & 66 \\
\hline Armenia & 0.89 & 0.39 & $\begin{array}{c}0.5 \\
4\end{array}$ & $\begin{array}{c}31.8 \\
9\end{array}$ & 0.14 & 0.29 & 0.57 & 0.46 & 0.29 & 28 \\
\hline Romania & 0.92 & 0.59 & $\begin{array}{c}0.4 \\
9\end{array}$ & $\begin{array}{c}37.0 \\
3\end{array}$ & 0.15 & 0.28 & 0.54 & 0.38 & 0.38 & 39 \\
\hline Vietnam & 0.92 & 0.73 & $\begin{array}{c}0.5 \\
4\end{array}$ & $\begin{array}{c}39.4 \\
5\end{array}$ & 0.11 & 0.21 & 0.67 & 0.52 & 0.34 & 368 \\
\hline Hungary & 0.96 & 0.58 & $\begin{array}{c}0.6 \\
3\end{array}$ & $\begin{array}{c}50.5 \\
4\end{array}$ & 0.17 & 0.25 & 0.50 & 0.08 & 0.21 & 24 \\
\hline Mean & 0.70 & 0.61 & $\begin{array}{c}0.5 \\
0\end{array}$ & $\begin{array}{c}43.0 \\
8\end{array}$ & 0.27 & 0.26 & 0.41 & 0.40 & 0.27 & \\
\hline Std. Dev. & 0.09 & 0.49 & $\begin{array}{c}0.5 \\
0\end{array}$ & $\begin{array}{c}12.6 \\
0\end{array}$ & 0.44 & 0.44 & 0.49 & 0.49 & 0.45 & \\
\hline
\end{tabular}

Note: Data comes from the 2016 American Community Survey (ACS) of Integrated Public Use Microdata Sample (IPUMS). The sample contains 8,313 observations of immigrants, aged 18 to 69, originating from 48 different countries.

Table 2: The effect of culture on the home-ownership decision

Dependent variable: Homeowner

$\mathrm{HCPH}$

HCPH by marital status
(1)

(2)

(3)

(4)

(5)

(6)

(7)

(8)
0.230 *

(0.110)

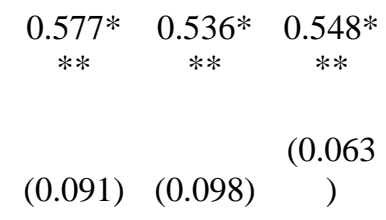

$1.167 *$

$0.493^{*}$

This article is protected by copyright. All rights reserved. 
and age

group (18-30, 31-43, 44$56,57-69)$

(0.059)

$(0.046$

HCPH by marital status, age and

$0.440 *$

employment status

(0.056)

Proportion of

$0.767 *$

homeowners by state

$(0.160$

)

Man

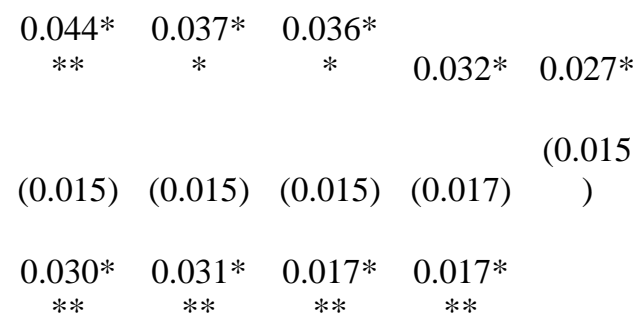

Age $^{2} / 100$

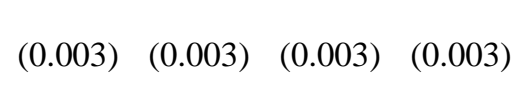

Some college

More college

$$
\begin{array}{ccccccccc}
(0.016) & (0.016) & (0.016) & (0.015) & ) & (0.023) & (0.019) & ) \\
0.113^{*} & 0.126 * & 0.129 * & 0.140 * & 0.124 * & 0.115^{*} & 0.118^{*} & 0.125^{*} \\
* * & * * & * * & * * & * * & * * & * * & * *
\end{array}
$$$$
\begin{array}{ccccccccc}
(0.027) & (0.028) & (0.027) & (0.023) & ) & (0.042) & (0.026) & (0.028 \\
0.196 * & 0.193 * & 0.198 * & 0.203^{*} & 0.187 * & 0.154 * & 0.216^{*} & 0.193 * \\
* * & * * & * * & * * & * * & * * & * * & * *
\end{array}
$$

$$
\begin{aligned}
& \begin{array}{llllllll}
(0.019) & (0.027) & (0.026) & (0.024) & )^{(0.031} & (0.036) & (0.028) & (0.027
\end{array} \\
& \begin{array}{cccccccc}
0.081 * & 0.059 * & 0.067 * & 0.067 * & & 0.069 * & 0.054 * & 0.058 * \\
* * & * * & * * & * * & 0.034 * & * * & * & * *
\end{array} \\
& \left.\begin{array}{llllllll}
(0.016) & (0.017) & (0.016) & (0.018) & )^{(0.018} & (0.014) & (0.024) & (0.017
\end{array}\right)
\end{aligned}
$$

Single or never married

This article is protected by copyright. All rights reserved. 


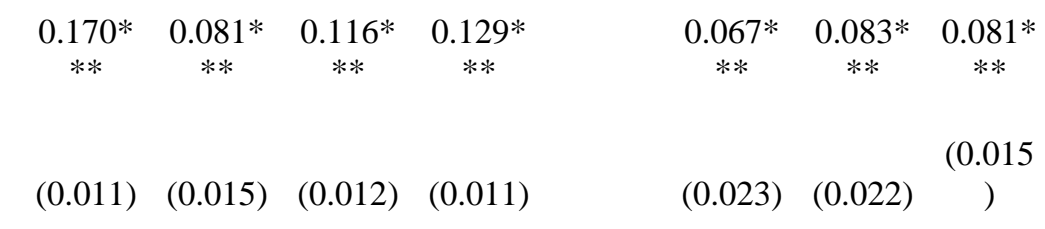

$\begin{array}{lccccccccc}\text { MSA fixed effects } & \text { Yes } & \text { Yes } & \text { Yes } & \text { Yes } & \text { Yes } & \text { Yes } & \text { Yes } & \text { Yes } \\ \begin{array}{l}\text { Country of origin fixed } \\ \text { effects }\end{array} & \text { No } & \text { Yes } & \text { Yes } & \text { Yes } & \text { Yes } & \text { Yes } & \text { Yes } & \text { Yes } \\ \text { Observations } & 8,313 & 8,313 & 8,313 & 8,104 & 8,313 & 4,198 & 4,115 & 8,313 \\ \mathrm{R}^{2} & 0.273 & 0.294 & 0.295 & 0.298 & 0.264 & 0.317 & 0.333 & 0.296\end{array}$

Notes: The home-country proportion of homeowners is calculated using information from the IPUMS International. The sample, obtained from the 2016 ACS, consists of immigrants aged 18 to 69 who arrived in the US at or before the age of 5 and who report their country of origin. In the first column, the home-country cultural proxy has been calculated by country of origin. In columns 2 to 4, that variable has been measured by marital status, marital status and age group, and marital status, age group and employment status, respectively. In column 5, controls for age and marital status have been excluded. Column 6 only incorporates immigrants who are men, and column 7 only incorporates immigrants who are women. Column 8 adds the proportion of homeowners in each US state using data from the IPUMS. Estimates are weighted. Robust standard errors, clustered by country of origin, are in parentheses. *** Significant at the 1 percent level, ** Significant at the 5 percent level, * Significant at the 10 percent level.

Table 3: Simple robustness checks

\begin{tabular}{|c|c|c|c|c|c|c|c|c|c|}
\hline $\begin{array}{l}\text { Dependent variable: } \\
\text { Homeowner }\end{array}$ & (1) & $(2)$ & (3) & (4) & (5) & (6) & (7) & (8) & (9) \\
\hline HCPH by marital status & $\begin{array}{c}0.543 \\
* * *\end{array}$ & $\begin{array}{c}0.550 \\
* * *\end{array}$ & $\begin{array}{c}0.563 \\
* * *\end{array}$ & $\begin{array}{c}0.703 \\
* * *\end{array}$ & & $\begin{array}{c}0.583 \\
* * *\end{array}$ & $\begin{array}{c}0.498 \\
* * *\end{array}$ & $\begin{array}{c}0.484 \\
* * *\end{array}$ & $\begin{array}{c}0.551 \\
* * *\end{array}$ \\
\hline & $\begin{array}{c}(0.063 \\
)\end{array}$ & $\begin{array}{c}(0.063 \\
)\end{array}$ & $\begin{array}{c}(0.079 \\
)\end{array}$ & $\begin{array}{c}0.108 \\
)\end{array}$ & & $\begin{array}{c}(0.035 \\
)\end{array}$ & $\begin{array}{c}(0.064 \\
)\end{array}$ & $\begin{array}{c}(0.096 \\
)\end{array}$ & $\begin{array}{c}0.095 \\
)\end{array}$ \\
\hline HCРН (Census 1970) & & & & & $\begin{array}{c}0.646 \\
* * * \\
\left(\begin{array}{c}0.116 \\
)\end{array}\right.\end{array}$ & & & & \\
\hline Man & $\begin{array}{c}0.037 \\
* *\end{array}$ & $\begin{array}{c}0.037 \\
* *\end{array}$ & 0.021 & $\begin{array}{c}0.041 \\
* *\end{array}$ & $\begin{array}{c}0.035 \\
* *\end{array}$ & $\begin{array}{c}0.026 \\
* * *\end{array}$ & 0.011 & & \\
\hline \multirow{3}{*}{ Age } & $\begin{array}{c}(0.015 \\
)\end{array}$ & $\begin{array}{c}(0.015 \\
)\end{array}$ & $\begin{array}{c}(0.016 \\
)\end{array}$ & $\begin{array}{c}(0.019 \\
)\end{array}$ & $\begin{array}{c}(0.013 \\
)\end{array}$ & $\begin{array}{c}(0.008 \\
)\end{array}$ & $\begin{array}{c}(0.009 \\
)\end{array}$ & & \\
\hline & $\begin{array}{c}0.031 \\
* * *\end{array}$ & $\begin{array}{c}0.031 \\
* * *\end{array}$ & $\begin{array}{c}0.031 \\
* * *\end{array}$ & 0.026 & $\begin{array}{c}0.031 \\
* * *\end{array}$ & $\begin{array}{c}0.036 \\
* * *\end{array}$ & $\begin{array}{c}0.036 \\
* * *\end{array}$ & $\begin{array}{c}0.038 \\
* * *\end{array}$ & $\begin{array}{c}0.035 \\
* * *\end{array}$ \\
\hline & $\begin{array}{c}(0.003 \\
)\end{array}$ & $\begin{array}{c}(0.003 \\
)\end{array}$ & $\begin{array}{c}(0.005 \\
)\end{array}$ & $\begin{array}{c}(0.030 \\
)\end{array}$ & $\begin{array}{c}(0.003 \\
)\end{array}$ & $\begin{array}{c}(0.002 \\
)\end{array}$ & $\begin{array}{c}(0.002 \\
)\end{array}$ & $\begin{array}{c}(0.003 \\
)\end{array}$ & $\begin{array}{c}(0.003 \\
)\end{array}$ \\
\hline $\operatorname{Age}^{2} / 100$ & $\begin{array}{c}- \\
0.020\end{array}$ & $\begin{array}{c}- \\
0.020\end{array}$ & $\begin{array}{c}- \\
0.020\end{array}$ & -0.012 & $\begin{array}{c}- \\
0.020\end{array}$ & $\begin{array}{c}- \\
0.026\end{array}$ & $\begin{array}{c}- \\
0.025\end{array}$ & $\begin{array}{c}- \\
0.027\end{array}$ & $\begin{array}{c}- \\
0.023\end{array}$ \\
\hline
\end{tabular}

This article is protected by copyright. All rights reserved. 


\begin{tabular}{|c|c|c|c|c|c|c|c|c|c|}
\hline & $* * *$ & $* * *$ & $* * *$ & & $* * *$ & $* * *$ & $* * *$ & $* * *$ & $* * *$ \\
\hline \multirow{5}{*}{ High school graduate } & $(0.004$ & $(0.004$ & $(0.006$ & $(0.038$ & $(0.004$ & $(0.002$ & $(0.003$ & $(0.004$ & $(0.003$ \\
\hline & ) & ) & ) & ) & ) & ) & ) & ) & ) \\
\hline & $\begin{array}{c}0.043 \\
* * *\end{array}$ & $\begin{array}{c}0.043 \\
* * *\end{array}$ & 0.030 & -0.004 & $\begin{array}{c}0.041 \\
* * *\end{array}$ & $\begin{array}{c}0.094 \\
* * *\end{array}$ & $\begin{array}{c}0.088 \\
* * *\end{array}$ & $\begin{array}{c}0.091 \\
* * *\end{array}$ & $\begin{array}{c}0.078 \\
* * *\end{array}$ \\
\hline & $(0.016$ & $(0.016$ & $(0.059$ & $(0.018$ & $(0.015$ & $(0.008$ & $(0.012$ & $(0.021$ & $(0.016$ \\
\hline & ) & ) & ) & ) & ) & ) & ) & ) & ) \\
\hline \multirow[t]{3}{*}{ Some college } & $\begin{array}{c}0.126 \\
* * *\end{array}$ & $\begin{array}{c}0.125 \\
* * *\end{array}$ & 0.078 & $\begin{array}{c}0.089 \\
*\end{array}$ & $\begin{array}{c}0.123 \\
* * *\end{array}$ & $\begin{array}{c}0.154 \\
* * *\end{array}$ & $\begin{array}{c}0.148 \\
* * *\end{array}$ & $\begin{array}{c}0.167 \\
* * *\end{array}$ & $\begin{array}{c}0.123 \\
* * *\end{array}$ \\
\hline & $(0.028$ & $(0.028$ & $(0.061$ & $(0.045$ & $(0.028$ & $(0.011$ & $(0.018$ & $(0.024$ & $(0.024$ \\
\hline & ) & ) & ) & ) & ) & ) & ) & ) & ) \\
\hline \multirow[t]{3}{*}{ More college } & $\begin{array}{c}0.193 \\
* * *\end{array}$ & $\begin{array}{c}0.194 \\
* * *\end{array}$ & $\begin{array}{c}0.149 \\
* *\end{array}$ & $\begin{array}{c}0.191 \\
* * *\end{array}$ & $\begin{array}{c}0.190 \\
* * *\end{array}$ & $\begin{array}{c}0.255 \\
* * *\end{array}$ & $\begin{array}{c}0.227 \\
* * *\end{array}$ & $\begin{array}{c}0.221 \\
* * *\end{array}$ & $\begin{array}{c}0.224 \\
* * *\end{array}$ \\
\hline & $(0.027$ & $(0.027$ & $(0.058$ & $(0.030$ & $(0.027$ & $(0.016$ & $(0.019$ & $(0.024$ & $(0.025$ \\
\hline & ) & ) & ) & ) & ) & ) & ) & ) & ) \\
\hline \multirow[t]{3}{*}{ Children under sixteen } & $\begin{array}{c}0.059 \\
* * *\end{array}$ & $\begin{array}{c}0.059 \\
* * *\end{array}$ & $\begin{array}{c}0.082 \\
* * *\end{array}$ & $\begin{array}{c}0.066 \\
* *\end{array}$ & $\begin{array}{c}0.055 \\
* * *\end{array}$ & $\begin{array}{c}0.017 \\
*\end{array}$ & $\begin{array}{c}0.060 \\
* *\end{array}$ & $\begin{array}{c}0.049 \\
* *\end{array}$ & $\begin{array}{c}0.073 \\
* *\end{array}$ \\
\hline & $(0.017$ & $(0.017$ & $(0.018$ & $(0.029$ & $(0.019$ & $(0.009$ & $(0.024$ & $(0.019$ & $(0.029$ \\
\hline & ) & ) & ) & ) & ) & ) & ) & ) & ) \\
\hline \multirow{4}{*}{ Single or never married } & - & - & - & - & - & - & - & - & - \\
\hline & $\begin{array}{c}0.082 \\
* * *\end{array}$ & $\begin{array}{c}0.081 \\
* * *\end{array}$ & $\begin{array}{c}0.075 \\
* * *\end{array}$ & $\begin{array}{c}0.057 \\
* * *\end{array}$ & $\begin{array}{c}0.097 \\
* * *\end{array}$ & $\begin{array}{c}0.083 \\
* * *\end{array}$ & $\begin{array}{c}0.116 \\
* * *\end{array}$ & $\begin{array}{c}0.109 \\
* * *\end{array}$ & $\begin{array}{c}0.120 \\
* * *\end{array}$ \\
\hline & $(0.015$ & $(0.015$ & $(0.023$ & $(0.017$ & $(0.013$ & $(0.010$ & $(0.013$ & $(0.021$ & $(0.017$ \\
\hline & ) & ) & ) & ) & ) & ) & ) & ) & ) \\
\hline MSA fixed effects & Yes & Yes & Yes & Yes & Yes & Yes & Yes & Yes & Yes \\
\hline $\begin{array}{l}\text { Country of origin fixed } \\
\text { effects }\end{array}$ & Yes & Yes & Yes & Yes & Yes & Yes & Yes & Yes & Yes \\
\hline Observations & 8,282 & 8,289 & 5,553 & 4,456 & 8,313 & $\begin{array}{c}25,25 \\
7\end{array}$ & $\begin{array}{c}13,45 \\
8\end{array}$ & 6,307 & 7,151 \\
\hline $\mathrm{R}^{2}$ & 0.293 & 0.294 & 0.309 & 0.240 & 0.298 & 0.261 & 0.291 & 0.309 & 0.316 \\
\hline
\end{tabular}

Note: The home-country proportion of homeowners is defined by marital status in all columns except in column 5 . Our cultural proxy is calculated for International Censuses of 1970 in column 6. In column 7, 2014 and 2015 ACS are included in addition to 2016 ACS. Columns 7 to 9 incorporate both head and non-heads of household.

Estimates are weighted. Robust standard errors, clustered by country of origin, are in parentheses. ${ }^{* * *}$ Significant at the 1 percent level, ** Significant at the 5 percent level, * Significant at the 10 percent level

This article is protected by copyright. All rights reserved. 
Table 4: The effect of culture on the home-ownership decision by year of migration and age

Dependent variable: Homeowner

(1)

(2)

(3)

(4)

HCPH by marital status

$$
\begin{aligned}
& \begin{array}{cccc}
0.571^{* *} & 0.989 * * * & 0.983^{* *} & 0.133 * \\
* & 0 & &
\end{array} \\
& \begin{array}{llll}
(0.066) \quad(0.307) \quad(0.323) & (0.073)
\end{array}
\end{aligned}
$$

1950s x HCPH by marital status

1960s x HCPH by marital status

1970s x HCPH by marital status

1980s x HCPH by marital status

1990s x HCPH by marital status

2000s x HCPH by marital status

30-39 years $\mathrm{x}$ HCPH by marital status

$0.561 * *$

*

(0.107)

$0.570 * *$

40-49 years $\mathrm{x}$ HCPH by marital status

50-59 years $\mathrm{x}$ HCPH by marital status

$0.450 * *$

$*$

(0.119)

60-69 years x HCPH by marital status

$0.551^{* *}$

This article is protected by copyright. All rights reserved. 


\begin{tabular}{|c|c|c|c|c|}
\hline MSA fixed effects & Yes & Yes & Yes & Yes \\
\hline Country of origin fixed effects & Yes & Yes & Yes & Yes \\
\hline Year of immigration fixed effect & Yes & No & No & No \\
\hline P-value (F-test of HCPH + $1950 \times \mathrm{HCPH})$ & & 0.003 & 0.004 & \\
\hline P-value (F-test of HCPH + $1960 \times$ XCPH) & & 0.000 & 0.000 & \\
\hline P-value (F-test of HCPH + 1970 x HCPH) & & 0.000 & 0.000 & \\
\hline P-value (F-test of HCPH + 1980 x HCPH) & & 0.000 & 0.000 & \\
\hline P-value (F-test of HCPH + 1990 x HCPH) & & 0.207 & 0.000 & \\
\hline P-value (F-test of HCPH + $2000 \times$ HCPH) & & 0.558 & & \\
\hline P-value (F-test of $\mathrm{HCPH}+30-40$ years x HC & $\mathrm{CPH}$ & & & 0.000 \\
\hline P-value (F-test of $\mathrm{HCPH}+40-50$ years $\times \mathrm{HC}$ & $\mathrm{CPH}$ & & & 0.000 \\
\hline P-value (F-test of $\mathrm{HCPH}+50-60$ years $\times \mathrm{HC}$ & $\mathrm{CPH}$ & & & 0.000 \\
\hline P-value (F-test of $\mathrm{HCPH}+60-69$ years $\times \mathrm{HC}$ & $\mathrm{CPH}$ & & & 0.000 \\
\hline Observations & 8,313 & 8,313 & 6,731 & 8,313 \\
\hline $\mathrm{R}^{2}$ & 0.302 & 0.299 & 0.233 & 0.299 \\
\hline
\end{tabular}

\begin{abstract}
Note: The home-country proportion of homeowners is defined by marital status in columns 1 to 4 . We have included all the controls for the individual characteristics defined in Equation 1. Column 3 only includes individuals older than 30 years old. Estimates are weighted. Robust standard errors, clustered by country of origin, are in parentheses. ${ }^{* *}$ Significant at the 1 percent level, ** Significant at the 5 percent level, * Significant at the 10 percent level.
\end{abstract}

Table 5: More robustness checks, adding home-country observable characteristics

Dependent variable:

Homeowner

(2)

(3)

(4)

(5)

$\mathrm{HCPH}$

$0.262^{* *}$

$(0.100)$

HCPH by marital status

$0.468^{* * *}$

$(0.062)$
$0.484^{* * *} \quad 0.470^{* * *}$

$(0.075)$

$(0.092)$

This article is protected by copyright. All rights reserved. 
HCPH by marital status and age

group (18-30, 31-43, 44-56, 57-

69)

HCPH by marital status, age and

employment status

Man

Age

Age $2 / 100$

High school graduate

Some college

More college

Children under sixteen

Single or never married

Property Prices Index

Property Rights Index

GDP pc

Unemployment rate
$0.421 * * *$

(0.051)

$0.380 * * *$

$(0.047)$

$\begin{array}{cccccc}0.040 * * & 0.034 * * & 0.033^{* *} & 0.029 & & \\ (0.016) & (0.016) & (0.016) & (0.018) & & \\ 0.032^{* * *} & 0.034 * * * & 0.021^{* * *} & 0.021^{* * * *} & 0.036^{* * *} & 0.031^{* * *} \\ (0.003) & (0.003) & (0.003) & (0.002) & (0.003) & (0.004)\end{array}$

$\begin{array}{cccccc}- & - & - & - & - & - \\ 0.021^{* * *} & 0.023^{* * *} & 0.013^{* * *} & 0.012^{* * *} & 0.026^{* * *} & 0.019^{* * *}\end{array}$

$\begin{array}{llllll}(0.003) & (0.003) & (0.003) & (0.003) & (0.004) & (0.004)\end{array}$

$\begin{array}{llllll}0.048 * * * & 0.047 * * * & 0.052 * * * & 0.056 * * * & 0.026 & 0.066 * * *\end{array}$

$\begin{array}{llllll}(0.012) & (0.012) \quad(0.012) & (0.012) & (0.023) & (0.017)\end{array}$

$0.111^{* * *} \quad 0.110^{* * *} \quad 0.113^{* * *} \quad 0.125^{* * *} \quad 0.091^{*} \quad 0.116^{* * *}$

$\begin{array}{llllll}(0.030) & (0.033) & (0.032) & (0.027) & (0.054) & (0.021)\end{array}$

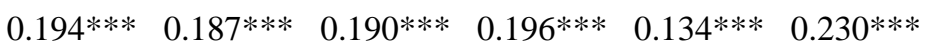

$\begin{array}{llllll}(0.024) & (0.026) & (0.026) & (0.023) & (0.040) & (0.019)\end{array}$

$\begin{array}{llllll}0.073^{* * *} & 0.056^{* * *} & 0.063^{* * *} & 0.063^{* * *} & 0.070^{* * *} & 0.043^{* *}\end{array}$

$\begin{array}{llllll}(0.016) & (0.017) \quad(0.016) \quad(0.017) \quad(0.014) \quad(0.020)\end{array}$

$\begin{array}{cccccc}- & - & - & - & - & - \\ 0.171^{* * *} & 0.095^{* * *} & 0.126^{* * *} & 0.137^{* * *} & 0.081^{* * *} & 0.102^{* * *}\end{array}$

$\begin{array}{llllll}(0.012) & (0.016) & (0.012) & (0.012) & (0.023) & (0.022)\end{array}$

$\begin{array}{llllll}0.001 & 0.0005 & -0.001 & -0.0004 & -0.001 & 0.002\end{array}$

$\begin{array}{llllll}(0.002) \quad(0.003) \quad(0.002) \quad(0.003) \quad(0.003) & (0.003)\end{array}$

$\begin{array}{llllll}-0.0005 & -0.001 & -0.001 & -0.001 & -0.002 & 0.001\end{array}$

$\begin{array}{llllll}(0.001) \quad(0.001) \quad(0.001) \quad(0.001) & (0.001) & (0.001)\end{array}$

$\begin{array}{llllll}0.002 * & 0.002 & 0.002 & 0.002 & 0.002 & 0.002\end{array}$

$(0.001) \quad(0.001) \quad(0.001) \quad(0.001) \quad(0.001) \quad(0.002)$

$\begin{array}{llllll}-0.001 & -0.001 & -0.001 & -0.001 & -0.004 & 0.001\end{array}$

$\begin{array}{lllll}(0.002) & (0.002) & (0.002) & (0.002) & (0.003)\end{array}$

This article is protected by copyright. All rights reserved. 


$\begin{array}{lcccccc}\text { Female labor force participation } & -0.002 & -0.003^{*} & -0.002 & -0.001 & -0.001 & -0.005^{* *} \\ & (0.001) & (0.001) & (0.001) & (0.001) & (0.002) & (0.002) \\ & \text { Yes } & \text { Yes } & \text { Yes } & \text { Yes } & \text { Yes } & \text { Yes } \\ \text { MSA fixed effects } & 7,885 & 7,885 & 7,885 & 7,677 & 3,987 & 3,898 \\ \text { Observations } & 0.282 & 0.290 & 0.290 & 0.294 & 0.307 & 0.325 \\ \mathrm{R}^{2} & & & & & \end{array}$

Note: In column 1, the home-country cultural proxy has been calculated by country of origin. In columns 2 to 4, that variable has been measured by marital status, marital status and age group, and marital status, age group and employment status, respectively. Column 5 only incorporates immigrants who are men, and column 6 only incorporates immigrants who are women. Estimates are weighted. Robust standard errors, clustered by country of origin, are in parentheses. *** Significant at the 1 percent level, ** Significant at the 5 percent level, * Significant at the 10 percent level.

Table 6: Home-ownership and mortgage finance culture
(1)
(2)
(3)
(4)
(5)

Multinomial Logit Model:

\begin{tabular}{|c|c|c|c|c|c|}
\hline Dependent variable: & $\begin{array}{c}\text { Homeowner } \\
\text { with } \\
\text { mortgage }\end{array}$ & $\begin{array}{l}\text { Homeowner } \\
\text { without } \\
\text { mortgage }\end{array}$ & $\begin{array}{l}\text { Homeowner } \\
\text { without } \\
\text { mortgage }\end{array}$ & $\begin{array}{l}\text { Homeowner } \\
\text { with a first } \\
\text { mortgage }\end{array}$ & $\begin{array}{l}\text { Homeowner } \\
\text { with a } \\
\text { second } \\
\text { mortgage }\end{array}$ \\
\hline \multirow[t]{2}{*}{ HCPH by marital status } & $0.633 * * *$ & $0.378 * * *$ & $1.791 * * *$ & $2.155^{* * *}$ & $3.390^{* * *}$ \\
\hline & $(0.077)$ & $(0.066)$ & $(0.373)$ & $(0.374)$ & $(0.750)$ \\
\hline \multirow[t]{2}{*}{ Man } & $0.038^{* *}$ & $0.022 *$ & $0.158^{* *}$ & $0.228 * * *$ & 0.119 \\
\hline & $(0.015)$ & $(0.011)$ & $(0.077)$ & $(0.072)$ & $(0.131)$ \\
\hline \multirow[t]{2}{*}{ Age } & $0.033^{* * *}$ & $-0.009 * * *$ & -0.011 & $0.165^{* * *}$ & $0.438 * * *$ \\
\hline & $(0.003)$ & $(0.003)$ & (0.029) & $(0.016)$ & $(0.051)$ \\
\hline \multirow[t]{2}{*}{$\mathrm{Age}^{2} / 100$} & $-0.023 * * *$ & $0.026^{* * *}$ & $0.099 * * *$ & $-0.123 * * *$ & $-0.358 * * *$ \\
\hline & $(0.004)$ & $(0.003)$ & $(0.030)$ & $(0.019)$ & $(0.050)$ \\
\hline \multirow[t]{2}{*}{ High school graduate } & $0.056^{* * *}$ & 0.007 & -0.152 & $0.201^{* *}$ & $0.702 * * *$ \\
\hline & $(0.019)$ & $(0.015)$ & $(0.141)$ & $(0.094)$ & $(0.259)$ \\
\hline \multirow[t]{2}{*}{ Some college } & $0.151^{* * *}$ & $0.049 * * *$ & -0.073 & $0.537 * * *$ & $1.302^{* * *}$ \\
\hline & $(0.032)$ & $(0.012)$ & $(0.131)$ & $(0.141)$ & $(0.318)$ \\
\hline More college & $0.231^{* * *}$ & $0.090^{* * *}$ & $0.294 * * *$ & $0.947^{* * *}$ & $2.024 * * *$ \\
\hline
\end{tabular}

This article is protected by copyright. All rights reserved. 


$\begin{array}{lccccc} & (0.032) & (0.016) & (0.105) & (0.099) & (0.323) \\ \text { Children under sixteen } & 0.066^{* * *} & 0.038^{* * *} & 0.269^{* * *} & 0.345^{* * *} & 0.431^{* *} \\ & (0.019) & (0.011) & (0.101) & (0.098) & (0.174) \\ \text { Single or never married } & -0.071^{* * *} & -0.033^{* *} & -0.422^{* * *} & -0.563^{* * *} & -0.453^{* *} \\ & (0.017) & (0.015) & (0.088) & (0.122) & (0.183) \\ \text { MSA fixed effects } & \text { Yes } & \text { Yes } & \text { No } & \text { No } & \text { No } \\ \text { Country fixed effects } & \text { Yes } & \text { Yes } & \text { No } & \text { No } & \text { No } \\ \text { Observations } & 7,071 & 4,451 & 8,313 & 8,313 & 8,313 \\ \mathrm{R}^{2} & 0.296 & 0.311 & & & \end{array}$

Note: The home-country proportion of homeowners has been defined by marital status. In column 1 , those homeowners without mortgage have been excluded from our sample. In column 2. those homeowners with mortgage have been excluded from our sample. In columns 3 to 5 , we study the effect of culture on home-ownership using a Multinomial Logit Model. Estimates are weighted. Robust standard errors, clustered by country of origin, are in parentheses. ${ }^{* *}$ Significant at the 1 percent level, ** Significant at the 5 percent level, * Significant at the 10 percent level.

\section{Table 7: Same- or different-origin couples (Heads of Household (HH) and their partners).}

Dependent

variable:

Homeowner

(1)

(2)

(3)

(4)

(5)

(6)

(7)

$\begin{array}{ccccc}\text { Sample } & \begin{array}{c}\text { Same } \\ \text { origin } \\ \text { couples }\end{array} & \begin{array}{c}\text { Different } \\ \text { origin } \\ \text { couples }\end{array} & \begin{array}{c}\text { Different } \\ \text { origin } \\ \text { couples }\end{array} & \begin{array}{c}\text { Different } \\ \text { origin } \\ \text { couples }\end{array}\end{array}$

All (excluding immigrants without their partner's $\mathrm{HCPH})$

$\mathrm{HCPH}$ of the $\mathrm{HH}$

for married and

$0.740^{* * *}$

0.105

Unmarried couples

(0.152)

HCPH of the HH's partner

$\begin{array}{ll}0.444 * & 0.598 * * \\ (0.251) & (0.236)\end{array}$

Mean between the $\mathrm{HCPH}$ of the $\mathrm{HH}$

and the HCPH of the HH's partner

HCPH by marital status

$0.888 *$

\section{All}




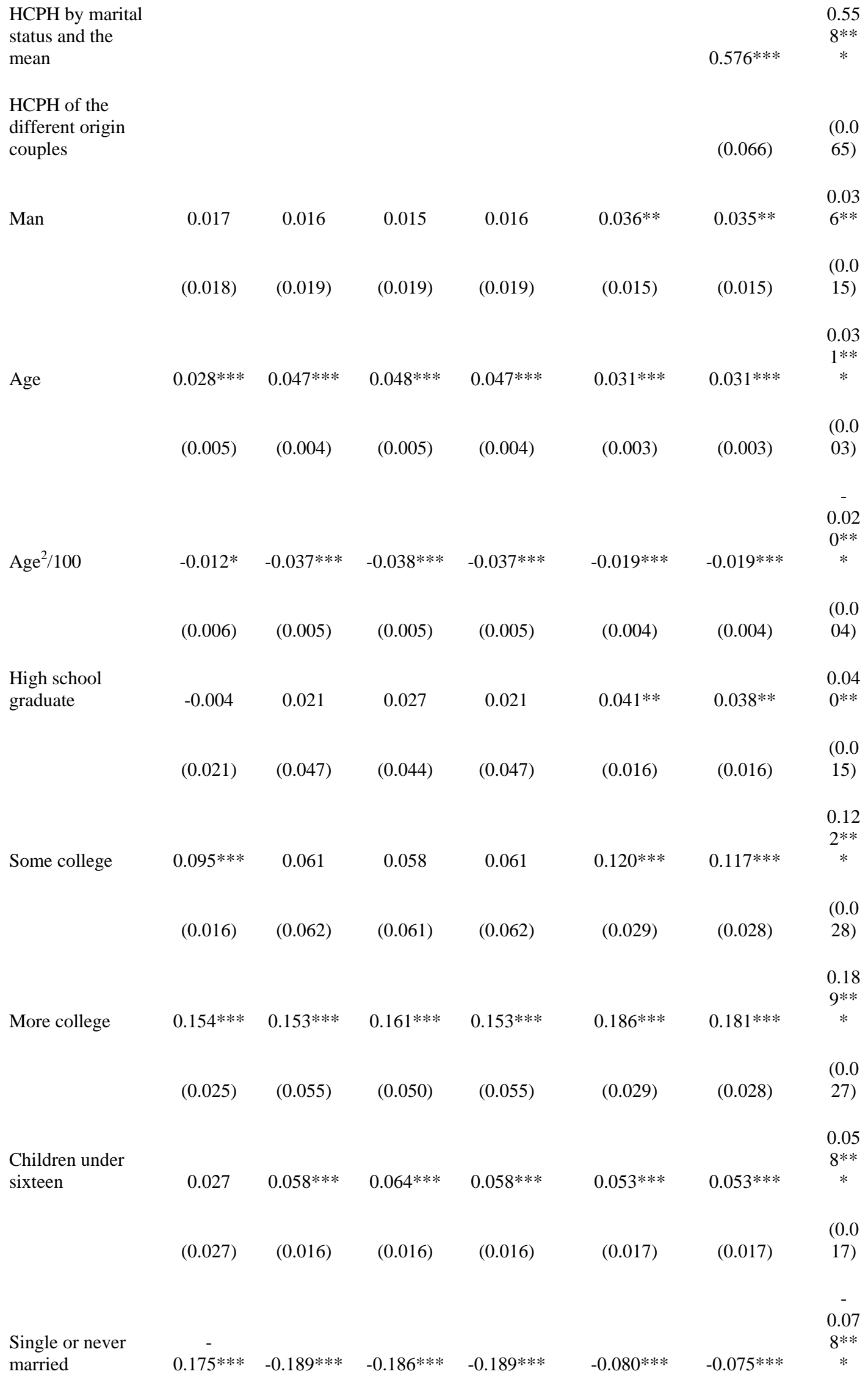




\begin{tabular}{|c|c|c|c|c|c|c|c|}
\hline & $(0.025)$ & $(0.030)$ & $(0.030)$ & $(0.030)$ & $(0.015)$ & $(0.015)$ & $\begin{array}{l}(0.0 \\
16)\end{array}$ \\
\hline MSA fixed effects & Yes & Yes & Yes & Yes & Yes & Yes & Yes \\
\hline $\begin{array}{l}\text { Country of origin } \\
\text { of the HH fixed } \\
\text { effects }\end{array}$ & No & Yes & No & Yes & Yes & Yes & Yes \\
\hline Observations & 1,466 & 3,319 & 3,319 & 3,319 & 8,039 & 8,039 & $\begin{array}{c}8,31 \\
3\end{array}$ \\
\hline $\mathrm{R}^{2}$ & 0.363 & 0.342 & 0.326 & 0.342 & 0.296 & 0.297 & $\begin{array}{c}0.29 \\
5\end{array}$ \\
\hline
\end{tabular}

Note: The home-country proportion of homeowners has been defined by marital status. Column 1 only includes those individuals with a same-ethnicity partner. Columns 2, 3 and 4 only include those individuals with different-origin partner. Those individuals with a different-origin partner for whom there is no information in IPUMS International have been excluded from our sample in columns 5 and 6. Estimates are weighted. Robust standard errors, clustered by country of origin, are in parentheses. ${ }^{* *}$ Significant at the 1 percent level, ** Significant at the 5 percent level, * Significant at the 10 percent level

\section{Table 8: Channels of transmission of culture}

Dependent variable: Homeowner

Proportion of individuals of the same origin by MSA

HCPH by marital status

Proportion of individuals of the same origin by MSA

X HCPH by marital status

Proportion of immigrant elders of

the same origin by MSA

Proportion of immigrant elders of

the same origin by MSA x HCPH

Gender-based system

Gender-based system x HCPH
(1)

(2)

(3)

(4)

(5)

$\begin{array}{ccc}-0.189 & -0.192 & - \\ & & - \\ (0.202) & (0.196) & (0.262) \\ & & \\ & 0.548^{* * * *} & \end{array}$

$(0.063)$

$2.882 * * *$

(0.293)

(0.303) 


\begin{tabular}{|c|c|c|c|c|c|}
\hline & $(0.015)$ & $(0.015)$ & $(0.014)$ & $(0.015)$ & $(0.014)$ \\
\hline \multirow[t]{2}{*}{ Age } & $0.030 * * *$ & $0.031 * * *$ & $0.030 * * *$ & $0.030 * * *$ & $0.030 * * *$ \\
\hline & $(0.003)$ & $(0.003)$ & $(0.003)$ & $(0.003)$ & $(0.003)$ \\
\hline \multirow[t]{2}{*}{$\operatorname{Age}^{2} / 100$} & $\overline{-}^{-} .018^{* * *}$ & $\begin{array}{c}- \\
0.020^{* * *}\end{array}$ & $\begin{array}{c}- \\
0.018^{* * *}\end{array}$ & $\begin{array}{c}- \\
0.018^{* * *}\end{array}$ & $\begin{array}{c}- \\
0.019 * * *\end{array}$ \\
\hline & $(0.003)$ & $(0.004)$ & $(0.003)$ & $(0.003)$ & $(0.004)$ \\
\hline \multirow[t]{2}{*}{ High school graduate } & $0.043^{* * *}$ & $0.043 * * *$ & $0.044 * * *$ & $0.044 * * *$ & $0.038 * *$ \\
\hline & $(0.015)$ & $(0.016)$ & $(0.015)$ & $(0.015)$ & $(0.016)$ \\
\hline \multirow[t]{2}{*}{ Some college } & $0.124 * * *$ & $0.126^{* * *}$ & $0.126 * * *$ & $0.125^{* * *}$ & $0.122 * * *$ \\
\hline & $(0.027)$ & $(0.028)$ & $(0.027)$ & $(0.027)$ & $(0.031)$ \\
\hline \multirow[t]{2}{*}{ More college } & $0.196 * * *$ & $0.193^{* * *}$ & $0.197 * * *$ & $0.197 * * *$ & $0.196 * * *$ \\
\hline & $(0.026)$ & $(0.027)$ & $(0.026)$ & $(0.026)$ & $(0.028)$ \\
\hline \multirow[t]{2}{*}{ Children under sixteen } & $0.080 * * *$ & $0.059 * * *$ & $0.077 * * *$ & $0.078 * * *$ & $0.065^{* * *}$ \\
\hline & $(0.018)$ & $(0.017)$ & $(0.019)$ & $(0.018)$ & $(0.018)$ \\
\hline \multirow[t]{2}{*}{ Single or never married } & $\begin{array}{c}- \\
0.167^{* * *}\end{array}$ & $\begin{array}{c}- \\
0.081^{* * *}\end{array}$ & $\begin{array}{c}- \\
0.151^{* * *}\end{array}$ & $\begin{array}{c}- \\
0.155^{* * *}\end{array}$ & $\begin{array}{c}- \\
0.079 * * *\end{array}$ \\
\hline & $(0.011)$ & $(0.015)$ & $(0.016)$ & $(0.013)$ & $(0.015)$ \\
\hline MSA fixed effects & Yes & Yes & Yes & Yes & Yes \\
\hline Country of origin fixed effects & Yes & Yes & Yes & Yes & Yes \\
\hline P-value (F-test of HCPH + Gender-based & & & & & 0.000 \\
\hline \multicolumn{6}{|l|}{ system x HCPH=0) } \\
\hline Observations & 8,313 & 8,313 & 8,313 & 8,313 & 7,9730 \\
\hline $\mathrm{R}^{2}$ & 0.285 & 0.294 & 0.287 & 0.286 & 0.295 \\
\hline
\end{tabular}

Note: The home-country proportion of homeowners has been defined by marital status. Estimates are weighted. Robust standard errors, clustered by country of origin, are in parentheses. *** Significant at the 1 percent level, ${ }^{* *}$ Significant at the 5 percent level, * Significant at the 10 percent level

\footnotetext{
${ }^{1}$ As in Borjas (2002), we restrict our sample to those heads of household aged 18 or older. We do not include immigrant over age 69 because the number of observations is very small for that age group.
} 


\footnotetext{
${ }^{2}$ This reference person (householder) is any household member in whose name the property is owned or rented, 2016 ACS. We revisit this issue below by extending the analysis to nonhouseholders.
}

${ }^{3}$ We have eliminated those individuals originating from countries with less than 10 observations per country of origin, as in prior studies (Furtado et al., 2013). We use all the observations from countries where we have information on the cultural proxy in the IPUMS International.
${ }^{4}$ Due to the non-availability of information in the IPUMS International for the variable measuring home-ownership status, we are not able to calculate the cultural proxy (home-ownership rate) for China, Cuba, Netherlands, and Ukraine. Then, we cannot include immigrants originating from those countries in our sample.
${ }^{5}$ This is a standard strategy, followed in the literature on the cultural effect. As Fernández (2007) points out, culture adjusts very slowly, and our findings do not vary after measuring the cultural proxy in other years (see below).

${ }^{6}$ As mentioned above, head of household (householder) is any household member in whose name
the property is owned or rented. This restriction implies losing individuals originating from
Germany since there is no information on householders for that country in the IPUMS International.

${ }^{7}$ Following Furtado et al. (2013), we use a linear probability model for the sake of simplicity. Our results are maintained applying a probit model, as can be seen in Table A1 (Appendix).

${ }^{8}$ Rodríguez-Planas (2018) uses similar controls.

${ }^{9}$ The incorporation of the country of origin fixed effects is not possible in all specifications (see below). We have repeated the regressions replacing MSA fixed effects with state fixed effects, and we do not find substantial differences. Our findings do not change when including/excluding the country of origin fixed effects.

\footnotetext{
${ }^{10}$ The married group includes those married and unmarried householders with a partner present in the household. Married individuals with spouse absent (194 observations) have been included in the
} 
separated and divorced group. Unmarried couples have been included here because there are some countries in which both categories are not separated in the IPUMS International. Thus, we follow Marcén and Morales (2018) who consider both categories together. Results do not change when excluding unmarried couples and/or those countries that do not distinguish between married and unmarried couples.

${ }^{11}$ The change in the sample size when the home-country cultural proxy is calculated by marital status, age group, and employment status is due to the non-availability of information for all categories.

${ }^{12}$ In the IPUMS USA, a metropolitan area is a region formed by neighboring communities that have a high degree of economic and social integration with the urban core. The population threshold to be classified as an MSA is 100,000 inhabitants.

${ }^{13}$ It is also possible to suggest the existence of possible endogeneity problems with some of the controls included in the analysis. Results do not vary when we exclude these controls. We have incorporated all these controls in the paper, as do other works examining the home-ownership decision.

${ }^{14}$ Note that, using the cultural proxy by marital status we do not lose observations, as in the case of the cultural proxy measured by employment status.

${ }^{15}$ See a similar strategy in Furtado et al. (2013) and Marcén et al. (2018).

${ }^{16}$ We have chosen country-of-origin Censuses as close as possible to the year 1970 (see Table A2 in the Appendix).

${ }^{17}$ The variation in the sample size is due to the availability of information for the 1970s.

${ }^{18}$ The omitted decade is the 1940 s.

${ }^{19}$ The relationship between culture and home-ownership can be more complex than that between culture and, for example, fertility, where the fertility culture has been detected even in teenagers (Bellido et al. 2016).

This article is protected by copyright. All rights reserved. 
${ }^{20}$ GDP per capita is gross domestic product divided by mid-year population. Unemployment rate is the percentage of the total labor force that is without work but available for and seeking employment. The female labor-force participation rate shows the extent to which women are active in the labor force. Labor force comprises individuals aged 15 and older who supply labor for the production of goods and services during a specified period. The property prices index is the basic measure for apartment purchase affordability (lower is better). It is generally calculated as the ratio of median apartment prices to median family disposable income, expressed as years of income. The property rights index varies between 0 and 100, and measures the degree to which a country's laws protect private property rights and the degree to which its government enforces those laws. It also assesses the likelihood that private property will be expropriated and analyzes the independence of the judiciary, the existence of corruption within the judiciary, and the ability of individuals and businesses to enforce contracts. The more effective the legal protection of property, the higher a country's score will be. Similarly, the greater the chances of government expropriation of property, the lower a country's score will be. This index is also used in Rodríguez-Planas (2018). Data are collected for the year 2016 (or for the closest year if no data is available for that year) and come from the World Bank Data (GDP pc, unemployment rate, and female labor force participation), from the Numbeo database (the property prices index), and from the Index of Economic Freedom (the property rights index).

${ }^{21}$ We do not have information on all these controls for the entire sample of countries of origin, so we lose around four thousand observations.

\footnotetext{
${ }^{22}$ We cannot include the country of origin fixed effects and the MSA fixed effects because with many controls the multinomial models do not converge.
}

${ }^{23}$ US native partners have been included in this analysis. We have re-estimated our regressions without those individuals and results are the same.

${ }^{24}$ In Table 6, head of household is denoted by “HH”.

${ }^{25}$ The cultural proxy is defined as the proportion of married and unmarried couples owning a home in each country of origin.

This article is protected by copyright. All rights reserved. 
${ }^{26}$ The variation in sample size is due to the availability of information for the gender-based system in the World Atlas of Language Structures Online.

This article is protected by copyright. All rights reserved. 